\title{
GNAQPMS-Hg v1.0, a global nested atmospheric mercury transport model: model description, evaluation and application to trans-boundary transport of Chinese anthropogenic emissions
}

 \\ ${ }^{1}$ LAPC, Institute of Atmospheric Physics, Chinese Academy of Sciences, Beijing, China \\ ${ }^{2}$ Lancaster Environment Centre, Lancaster University, Lancaster, UK \\ ${ }^{3}$ Center for Global and Regional Environmental Research (CGRER), University of Iowa, Iowa City, Iowa, USA
}

Correspondence to: Z. F. Wang (zifawang@mail.iap.ac.cn)

Received: 1 September 2014 - Published in Geosci. Model Dev. Discuss.: 22 October 2014

Revised: 25 August 2015 - Accepted: 27 August 2015 - Published: 11 September 2015

\begin{abstract}
Atmospheric mercury $(\mathrm{Hg})$ is a toxic pollutant and can be transported over the whole globe due to its long lifetime in the atmosphere. For the purpose of assessing $\mathrm{Hg}$ hemispheric transport and better characterizing regional $\mathrm{Hg}$ pollution, a global nested atmospheric Hg transport model (GNAQPMS-Hg - Global Nested Air Quality Prediction Modeling System for $\mathrm{Hg}$ ) has been developed. In GNAQPMS-Hg, the gas- and aqueous-phase $\mathrm{Hg}$ chemistry representing the transformation among three forms of $\mathrm{Hg}$ : elemental mercury $(\mathrm{Hg}(0))$, divalent mercury $(\mathrm{Hg}(\mathrm{III}))$, and primary particulate mercury $(\mathrm{Hg}(\mathrm{P}))$ are calculated. A detailed description of the model, including mercury emissions, gas- and aqueous-phase chemistry, and dry and wet deposition is given in this study. Worldwide observations including extensive data in China have been collected for model evaluation. Comparison results show that the model reasonably simulates the global mercury budget and the spatiotemporal variation of surface mercury concentrations and deposition. Overall, model predictions of annual total gaseous mercury (TGM) and wet deposition agree with observations within a factor of 2, and within a factor of 5 for oxidized mercury and dry deposition. The model performs significantly better in North America and Europe than in East Asia. This can probably be attributed to the large uncertainties in emission inventories, coarse model resolution and to the inconsistency between the simulation and observation periods in East Asia. Compared to the global simulation, the nested simulation shows improved skill at capturing the high spatial variability of surface $\mathrm{Hg}$ concentrations and deposition over East Asia.
\end{abstract}

In particular, the root mean square error (RMSE) of simulated $\mathrm{Hg}$ wet deposition over East Asia is reduced by $24 \%$ in the nested simulation. Model sensitivity studies indicate that Chinese primary anthropogenic emissions account for 30 and $62 \%$ of surface mercury concentrations and deposition over China, respectively. Along the rim of the western Pacific, the contributions from Chinese sources are 11 and $15.2 \%$ over the Korean Peninsula, 10.4 and $8.2 \%$ over Southeast Asia, and 5.7 and $5.9 \%$ over Japan. But for North America, Europe and western Asia, the contributions from China are all below $5 \%$.

\section{Introduction}

Since the Minamata event in Japan in the 1960s (Harada, 1995), the toxicity of mercury $(\mathrm{Hg})$ on human health and the environment has caused widespread public concern. $\mathrm{Hg}$ is a persistent bio-accumulated pollutant, and the only heavy metal that can be transported globally in gaseous form (Schroeder and Munthe, 1998). As a result, $\mathrm{Hg}$ has been listed as a priority pollutant by many countries and international agencies. After a long struggle, the first global treaty (the Minamata Convention) aimed at reducing $\mathrm{Hg}$ emissions and releases was adopted and signed by 92 countries in 2013 (http://www.mercuryconvention.org/). This made an important advance towards joint action to control global Hg pollution and has brought higher requirements for understanding global $\mathrm{Hg}$ source-receptor relationships, especially the 
impacts of high regional emissions (e.g., from China and India) on global $\mathrm{Hg}$ levels. However, besides the remaining uncertainties in emission estimates, poor understanding of the chemical transformation of atmospheric mercury has made assessment of long-range transport very challenging (AMAP/UNEP, 2013).

Atmospheric mercury models are powerful tools to assess the fate and transport of mercury in the atmosphere. A number of atmospheric mercury models have been developed to investigate the emissions, transport, chemistry, deposition and source-receptor relationships of $\mathrm{Hg}$ at global and regional scales. Global models include the GEOS-Chem model (Goddard Earth Observing System-Chemistry; Amos et al., 2012; Zhang et al., 2012), the CTM-Hg model (Chemistry Transport Model for Hg; Seigneur et al., 2004), the CAM-Chem-Hg model (Community Atmospheric Model with Chemistry for Hg; Lei et al., 2013), the ECHMERIT model (ECHAM5-MERcury-ITaly; De Simone et al., 2014), the MSCE-Hg-Hem model (Meteorological Synthesizing Centre-East Hemispheric Hg model; Travnikov and Ilyin, 2009), the DEHM model (Danish Eulerian Hemispheric Model; Christensen et al., 2004), and the GRAHM model (Global/Regional Atmospheric Heavy Metals; Dastoor and Durnford, 2014). Regional models include the CMAQ-Hg model (Community Multi-scale Air Quality model for Hg; Bash, 2010), the STEM-Hg model (Sulfur Transport and dEposition Model for Hg; Pan et al., 2008), the CAMx-Hg model (Comprehensive Air Quality Model with Extensions for $\mathrm{Hg}$; ENVIRON, 2011) and the WRF-Chem-Hg model (Weather Research and Forecasting model with Chemistry for $\mathrm{Hg}$; Gencarelli et al., 2014). Application of these models has greatly advanced our understanding of the global $\mathrm{Hg}$ cycle. However, several model intercomparison studies (Ryaboshapko et al., 2007; Bullock Jr. et al., 2008; Pirrone and Keating, 2010) have found that large uncertainties still exist in Hg models and there is much room for improvement, especially for simulation of reactive gaseous mercury (RGM) and dry deposition.

Mercury is released to the atmosphere from both anthropogenic and natural sources. Human activities have increased the amount of mercury cycling through the atmosphereocean-terrestrial system by about a factor of 3 (Selin, 2009), although anthropogenic sources are estimated to account for only $31 \%$ of total $\mathrm{Hg}$ emissions (Pirrone et al., 2010). China has the world's largest $\mathrm{Hg}$ production, consumption and emissions and suffers the most serious $\mathrm{Hg}$ pollution (Jiang et al., 2006), but the impacts of its anthropogenic emissions on global $\mathrm{Hg}$ levels are still unclear. Previous modeling studies mainly focused on long-range transport of mercury from Asia. Based on the GEOS-Chem model, about 7-20\% of $\mathrm{Hg}$ deposition over the USA was found to originate from Asian anthropogenic sources, which was comparable to that from North American sources (Strode et al., 2008; Jaffe and Strode, 2008). Another modeling study using the CTM-Hg model with three emission scenarios indi- cated that Asian anthropogenic emissions accounted for 14$25 \%$ of $\mathrm{Hg}$ deposition over the USA (Seigneur et al., 2004). Travnikov (2005) reported a contribution to $\mathrm{Hg}$ deposition from total Asian sources (including both anthropogenic and natural emissions) of $15 \%$ over Europe and $33 \%$ over the Arctic. Corbitt et al. (2011) further pointed out that Asian emissions are the largest contributors to anthropogenic deposition to all ocean basins and these contributions are expected to further grow in the future. The above studies all treated Asian anthropogenic emissions as a whole, and the effects of anthropogenic emissions from the world's largest single emitter (China) have not been explicitly assessed before. In addition, due to lack of observational data, little model validation has been conducted over East Asia (especially China) in these studies and this leads to greater uncertainty in the conclusions. Fu et al. (2012) reviewed previous modeling studies and pointed out that current model simulations tend to underestimate total gaseous mercury (TGM) and total particulate mercury (TPM) concentrations but overestimate reactive gaseous mercury (RGM) concentrations in China. To improve $\mathrm{Hg}$ model skill in China, nested simulations with high horizontal resolution might be a good choice. Zhang et al. (2012) demonstrated that a nested-grid model can capture the variation of $\mathrm{Hg}$ wet deposition over North America better than a global model. In this study, an online nested $\mathrm{Hg}$ simulation with flexible horizontal resolution was developed and evaluated. Compared to the traditional multi-scale modeling approach (using a global model to provide initial and boundary conditions to a regional model) (Seigneur et al., 2001), the online nested method uses the same physical and chemical parameterizations in the global and nested domains, which could avoid uncertainties induced by different boundary conditions. Compared to the offline nested method used in the GEOS-Chem model (Zhang et al., 2012), the online nested method can provide boundary conditions with higher time resolution (10 or $5 \mathrm{~min}$ ) from the global domain to the nested domain. Hence, the online nested simulation would potentially improve model performance at a regional scale.

Therefore, a comprehensive evaluation and improvement of $\mathrm{Hg}$ model performance in China is needed to effectively reduce the uncertainties in $\mathrm{Hg}$ trans-boundary transport, and a quantitative assessment of Chinese anthropogenic contributions to global $\mathrm{Hg}$ concentration and deposition levels is helpful to determine and fulfill the $\mathrm{Hg}$ emission reduction tasks under the Minamata Convention.

In this paper, we describe the development of a global nested atmospheric mercury transport model (GNAQPMS$\mathrm{Hg}$ - Global Nested Air Quality Prediction Modeling System for $\mathrm{Hg}$ ) incorporating the latest available physical and chemical processes essential to the mercury life cycle. The spatial and temporal variability of $\mathrm{Hg}$ concentrations and deposition are comprehensively evaluated against available worldwide observations, including extensive data from China. The impact of horizontal resolution $\left(1^{\circ} \times 1^{\circ}\right.$ in the global domain 
versus $0.33^{\circ} \times 0.33^{\circ}$ in the nested domain) on model predictions over East Asia is examined. Finally, the trans-boundary transport of Chinese primary anthropogenic $\mathrm{Hg}$ emissions is quantified using the model.

\section{Model description and setup}

\subsection{General description}

The atmospheric physics and chemistry component of GNAQPMS-Hg, with the exception of the mercury module, is based on the Nested Air Quality Prediction Modeling System for Hg (NAQPMS) (Wang et al., 2006), developed at the Institute of Atmospheric Physics, Chinese Academy of Sciences. NAQPMS is a 3-D regional Eulerian model which has been rigorously evaluated and widely applied to simulate the chemical evolution and transport of ozone ( $\mathrm{Li}$ et al., 2007; Tang et al., 2010), the distribution and evolution of aerosol and acid rain over East Asia (Wang et al., 2002; Li et al., 2011; Li et al., 2012) and to provide operational air quality forecasts in megacities such as Beijing, Shanghai and Guangzhou (Wang et al., 2010; Wu et al., 2012; Wang et al., 2009). GNAQPMS is the global version of NAQPMS and uses the same model framework and physical and chemical parameterization schemes.

As a multi-scale model, GNAQPMS can simulate the transportation and formation of primary and secondary pollutants from urban to global scales using an online nesting approach. It includes advection, diffusion and convection processes, gas/aqueous/aerosol chemistry, and modules for dry and wet deposition. The advection process is parameterized based on an accurate mass conservative, peak-preserving algorithm provided by Walcek and Aleksic (1998). The gasphase chemical mechanism is the CBM-Z mechanism (Carbon Bond Mechanism version Z; Zaveri and Peters, 1999), including 133 reactions for 53 species. The dry deposition module uses the parameterization of Wesely (1989). The wet deposition and aqueous-phase chemistry module is constructed based on a revised version of the RADM mechanism (Regional Acid Deposition Model; Chang et al., 1987; Wang et al., 2002; Ge et al., 2014). A mercury module has been developed and coupled into the GNAQPMS model in this study, as described in Sects. 2.2-2.4. Hereafter, we call this new model GNAQPMS-Hg. Note that meteorology, emissions, deposition and chemistry are self-consistent between the global and nested domains.

\subsection{Mercury chemistry}

\subsubsection{Basic mechanism}

In GNAQPMS-Hg, three forms of mercury are explicitly treated: elemental mercury $(\mathrm{Hg}(0))$, divalent mercury $(\mathrm{Hg}(\mathrm{II}))$, and primary particulate mercury $(\mathrm{Hg}(\mathrm{P}))$. Transformations between these three forms include the gas-phase ox-

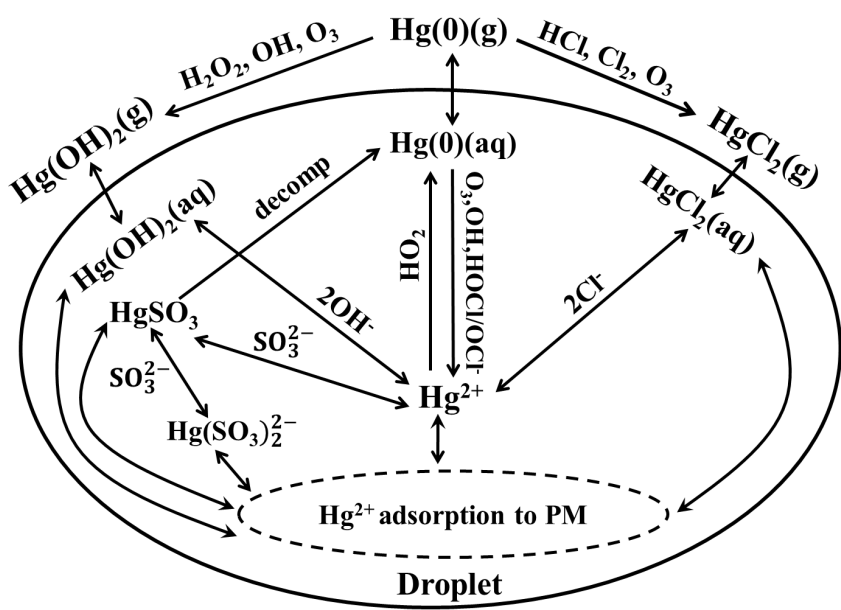

Figure 1. Schematic of different mercury reactions utilized in the GNAQPMS-Hg model.

idation of $\mathrm{Hg}(0)$ to $\mathrm{Hg}(\mathrm{II})$, the aqueous-phase oxidation of $\mathrm{Hg}(0)$ to $\mathrm{Hg}(\mathrm{II})$, the aqueous-phase reduction of $\mathrm{Hg}(\mathrm{II})$ to $\mathrm{Hg}(0)$, the aqueous-phase equilibria of $\mathrm{Hg}(\mathrm{II})$ species and the aqueous-phase adsorption of $\mathrm{Hg}$ (II) to PM. Figure 1 depicts the mercury reaction pathways both in the gas and aqueous phase while the detailed reactions and their rate constants are summarized in Table 1. In line with most global mercury models, GNAQPMS-Hg does not include dynamic airsurface exchange during mercury depletion events (MDEs) in polar regions (Schroeder et al., 1998) due to lack of fundamental data.

In the gas phase, $\mathrm{Hg}(0)$ is oxidized to $\mathrm{Hg}(\mathrm{II})$ by $\mathrm{O}_{3}, \mathrm{OH}$, hydrogen peroxide $\left(\mathrm{H}_{2} \mathrm{O}_{2}\right)$, hydrogen chloride $(\mathrm{HCl})$ and molecular chlorine $\left(\mathrm{Cl}_{2}\right)$. The oxidized products of these five reactions are assumed to be in the gas phase. According to Lin et al. (2004), $\mathrm{OH}$ and $\mathrm{O}_{3}$ are the dominant oxidants in the continental troposphere while $\mathrm{Cl}$ and $\mathrm{Br}$ dominate $\mathrm{Hg}(0)$ oxidation in the marine boundary layer and the upper troposphere. In the aqueous phase, $\mathrm{Hg}(0)$ is oxidized to $\mathrm{Hg}(\mathrm{II})$ by dissolved $\mathrm{O}_{3}, \mathrm{OH}$, and $\mathrm{Cl}_{2}$, and $\mathrm{Hg}$ (II) can be reduced back to $\mathrm{Hg}(0)$ via reaction with $\mathrm{HO}_{2}$ and by the formation of sulfite complexes. In addition, adsorption of $\mathrm{Hg}(\mathrm{II})$ species on atmospheric particulate matter (PM) is simulated using an adsorption coefficient $\left(K=34 \mathrm{Lg}^{-1}\right)$ recommended by Seigneur et al. (1998).

As shown in Table 1, the mercury chemistry requires the concentrations of several non-mercury species, among which $\mathrm{O}_{3}, \mathrm{OH}, \mathrm{HO}_{2}, \mathrm{H}_{2} \mathrm{O}_{2}, \mathrm{SO}_{2}, \mathrm{HCl}$ and $\mathrm{PM}$ are simulated online with GNAQPMS-Hg. However, $\mathrm{Cl}_{2}$ is not explicitly simulated, and a typical vertical profile of $\mathrm{Cl}_{2}$ concentrations is therefore prescribed. The $\mathrm{Cl}_{2}$ concentrations are specified to be $100 \mathrm{ppt}$ at the surface, $50 \mathrm{ppt}$ aloft at night, $10 \mathrm{ppt}$ during daytime over the oceans, and zero over land (Seigneur et al., 2001). 
Table 1. Reactions and rate constants used in the GNAQPMS-Hg model.

\begin{tabular}{|c|c|c|c|}
\hline No. & Reaction & Rates $(k \text { or } K)^{*}$ & References \\
\hline \multicolumn{4}{|c|}{ Gas-phase reactions } \\
\hline RG1 & $\mathrm{Hg}(0)(\mathrm{g})+\mathrm{O}_{3}(\mathrm{~g}) \rightarrow \mathrm{Hg}(\mathrm{II})(\mathrm{g})$ & $3 \times 10^{-20} \mathrm{~cm}^{3} \mathrm{molec}^{-1} \mathrm{~s}^{-1}$ & Hall (1995) \\
\hline RG2 & $\mathrm{Hg}(0)(\mathrm{g})+\mathrm{HCl}(\mathrm{g}) \rightarrow \mathrm{HgCl}_{2}(\mathrm{~g})$ & $1 \times 10^{-19} \mathrm{~cm}^{3}$ molec $^{-1} \mathrm{~s}^{-1}$ & Hall and Bloom (1993) \\
\hline RG3 & $\mathrm{Hg}(0)(\mathrm{g})+\mathrm{H}_{2} \mathrm{O}_{2}(\mathrm{~g}) \rightarrow \mathrm{Hg}(\mathrm{OH})_{2}(\mathrm{~g})$ & $8.5 \times 10^{-19} \mathrm{~cm}^{3} \mathrm{molec}^{-1} \mathrm{~s}^{-1}$ & Tokos et al. (1998) \\
\hline RG4 & $\mathrm{Hg}(0)(\mathrm{g})+\mathrm{Cl}_{2}(\mathrm{~g}) \rightarrow \mathrm{HgCl}_{2}(\mathrm{~g})$ & $2.6 \times 10^{-18} \mathrm{~cm}^{3} \mathrm{molec}^{-1} \mathrm{~s}^{-1}$ & Ariya et al. (2002) \\
\hline RG5 & $\mathrm{Hg}(0)(\mathrm{g})+\mathrm{OH}(\mathrm{g}) \rightarrow \mathrm{Hg}(\mathrm{OH})_{2}(\mathrm{~g})$ & $8 \times 10^{-14} \mathrm{~cm}^{3}$ molec $^{-1} \mathrm{~s}^{-1}$ & Sommar et al. (2001) \\
\hline \multicolumn{4}{|c|}{ Gas-liquid equilibria } \\
\hline GL1 & $\operatorname{Hg}(0)(\mathrm{g}) \leftrightarrow \operatorname{Hg}(0)(\mathrm{aq})$ & $0.11 \mathrm{M} \mathrm{atm}^{-1}$ & Sanemasa (1975) \\
\hline GL2 & $\mathrm{HgCl}_{2}(\mathrm{~g}) \leftrightarrow \mathrm{HgCl}_{2}(\mathrm{aq})$ & $1.4 \times 10^{6} \mathrm{M} \mathrm{atm}^{-1}$ & Lindqvist and Rodhe (1985) \\
\hline GL3 & $\mathrm{Hg}(\mathrm{OH})_{2}(\mathrm{~g}) \leftrightarrow \mathrm{Hg}(\mathrm{OH})_{2}(\mathrm{aq})$ & $1.2 \times 10^{4} \mathrm{M} \mathrm{atm}^{-1}$ & Lindqvist and Rodhe (1985) \\
\hline \multicolumn{4}{|c|}{ Aqueous-phase equilibria } \\
\hline AE1 & $\mathrm{HgCl}_{2}(\mathrm{aq}) \leftrightarrow \mathrm{Hg}^{2+}+2 \mathrm{Cl}^{-}$ & $1 \times 10^{-14} \mathrm{M}^{2}$ & Sillen et al. (1964) \\
\hline AE2 & $\mathrm{Hg}(\mathrm{OH})_{2}(\mathrm{aq}) \leftrightarrow \mathrm{Hg}^{2+}+2 \mathrm{OH}^{-}$ & $1 \times 10^{-22} \mathrm{M}^{2}$ & Sillen et al. (1964) \\
\hline AE3 & $\mathrm{Hg}^{2+}+\mathrm{SO}_{3}^{2-} \leftrightarrow \mathrm{HgSO}_{3}$ & $2.1 \times 10^{13} \mathrm{M}^{-1}$ & Van Loon et al. (2001) \\
\hline AE4 & $\mathrm{HgSO}_{3}+\mathrm{SO}_{3}^{2-} \leftrightarrow \mathrm{Hg}\left(\mathrm{SO}_{3}\right)_{2}^{2-}$ & $1 \times 10^{10} \mathrm{M}^{-1}$ & Van Loon et al. (2001) \\
\hline \multicolumn{4}{|c|}{ Aqueous-phase reaction } \\
\hline RA1 & $\mathrm{Hg}(0)(\mathrm{aq})+\mathrm{O}_{3}(\mathrm{aq}) \rightarrow \mathrm{Hg}^{2+}$ & $4.7 \times 10^{7} \mathrm{M}^{-1} \mathrm{~s}^{-1}$ & Munthe (1992) \\
\hline RA2 & $\mathrm{Hg}(0)(\mathrm{aq})+\mathrm{OH}(\mathrm{aq}) \rightarrow \mathrm{Hg}^{2+}$ & $2 \times 10^{9} \mathrm{M}^{-1} \mathrm{~s}^{-1}$ & Lin and Pehkonen (1997) \\
\hline RA3 & $\mathrm{HgSO}_{3}(\mathrm{aq}) \rightarrow \mathrm{Hg}(0)(\mathrm{aq})$ & $0.0106 \mathrm{~s}^{-1}$ & Van Loon et al. (2000) \\
\hline RA4 & $\mathrm{Hg}(\mathrm{II})(\mathrm{aq})+\mathrm{HO}_{2}(\mathrm{aq}) \rightarrow \mathrm{Hg}(0)(\mathrm{aq})$ & $1.7 \times 10^{4} \mathrm{M}^{-1} \mathrm{~s}^{-1}$ & Pehkonen and Lin (1998) \\
\hline RA5 & $\mathrm{Hg}(0)(\mathrm{aq})+\mathrm{HOCl}(\mathrm{aq}) \rightarrow \mathrm{Hg}^{2+}$ & $2.09 \times 10^{6} \mathrm{M}^{-1} \mathrm{~s}^{-1}$ & Lin and Pehkonen (1998) \\
\hline RA6 & $\mathrm{Hg}(0)(\mathrm{aq})+\mathrm{OCl}^{-} \rightarrow \mathrm{Hg}^{2+}$ & $1.99 \times 10^{6} \mathrm{M}^{-1} \mathrm{~s}^{-1}$ & Lin and Pehkonen (1998) \\
\hline \multicolumn{4}{|c|}{ Adsorption of $\mathrm{Hg}(\mathrm{II})$ on $\mathrm{PM}$ in the aqueous phase } \\
\hline AD1 & $\mathrm{Hg}(\mathrm{II})(\mathrm{aq}) \leftrightarrow \mathrm{Hg}(\mathrm{II})(\mathrm{p})$ & $34 \mathrm{Lg}^{-1}$ & Seigneur et al. (1998) \\
\hline
\end{tabular}

* The reaction rate constants are for temperatures in the range of $20-25^{\circ} \mathrm{C}$. No temperature dependence information is available.

\subsubsection{Bromine oxidation}

In order to test the effect of bromine $(\mathrm{Br})$ oxidation reactions on global $\mathrm{Hg}$ concentrations, five $\mathrm{Br}$ chemical reactions in the gas phase are added in addition to the $\mathrm{O}_{3}-\mathrm{OH}$ oxidation mechanism. The detailed description of the $\mathrm{Br}$ chemical reactions and their implementation in the model is shown in Sect. S1.1 in the Supplement. A model sensitivity experiment with additional $\mathrm{Br}$ oxidation reactions was conducted and compared to the base case simulation with the $\mathrm{O}_{3}-\mathrm{OH}$ oxidation mechanism. Figure S1 in the Supplement shows the difference of surface TGM concentrations resulting from introducing Br oxidation reactions. A decrease in TGM concentrations is found throughout the globe. This is because additional $\mathrm{Br}$ chemistry transforms more $\mathrm{Hg}(0)$ into $\mathrm{Hg}(\mathrm{II})$, which subsequently enhances the deposition of $\mathrm{Hg}$ (II), leading to the reduction of TGM concentrations. A larger TGM reduction is found in the Northern Hemisphere than in the Southern Hemisphere. In general, the change in TGM concentration is less than $0.2 \mathrm{ng} \mathrm{m}^{-3}$ in most areas, which indi- cates that introducing $\mathrm{Br}$ chemistry seems to have little impact on overall TGM magnitudes and patterns. These results are similar to those of Lei et al. (2013) which test the impact of $\mathrm{Br}$ chemistry using the CAM-Chem-Hg model. Although adding the $\mathrm{Br}$ chemistry does not significantly change the TGM pattern, it may affect the gaseous $\mathrm{Hg}$ partitioning between $\mathrm{Hg}(0)$ and $\mathrm{Hg}(\mathrm{II})$ and hence may affect the global $\mathrm{Hg}$ deposition patterns. More in-depth tests and analyses are needed to address these impacts in the future. In the following sections, we still use the base case simulated results without considering the possible effects of $\mathrm{Br}$ chemistry.

\subsubsection{Gas-particle partitioning of $\mathrm{Hg}(\mathrm{II})$}

Recent studies suggested that gas-particle partitioning of $\mathrm{Hg}$ (II) is an important process affecting global $\mathrm{Hg}$ concentrations and deposition (Amos et al., 2012). To test these effects, an empirical mechanism of gas-particle partitioning of $\mathrm{Hg}(\mathrm{II})$ was added to the GNAQPMS-Hg model. The detailed description of this mechanism and its implementation 
in the model is shown in Sect. S1.2 in the Supplement. A model sensitivity experiment with a $\mathrm{Hg}$ (II) gas-particle partitioning module was conducted and compared to the base case simulation with all $\mathrm{Hg}$ (II) existing in the gas phase. Figures S2-S3 in the Supplement show the change fraction of surface TGM concentrations and oxidized $\mathrm{Hg}$ concentrations resulting from introducing the $\mathrm{Hg}(\mathrm{II})$ gas-particle partitioning mechanism. As expected, TGM concentrations decrease while oxidized $\mathrm{Hg}$ concentrations increase in the whole globe. The change fractions of TGM and oxidized $\mathrm{Hg}$ concentrations are smaller than 0.1 over the middle latitude of the Northern Hemisphere and even smaller than 0.05 over China. Considering that the base case simulation has overestimated oxidized $\mathrm{Hg}$ concentrations in most areas, introducing the mechanism of gas-particle partitioning of $\mathrm{Hg}$ (II) would further increase this model discrepancy. Therefore, we still use the base case simulated results without considering the possible effects of gas-particle partitioning of $\mathrm{Hg}$ (II) in the following sections.

\subsection{Mercury deposition}

Deposition is the leading removal process of atmospheric mercury and also a major cause of mercury contamination in soil and water. Studies have shown that both dry and wet removal pathways are equally significant for the total deposition of mercury (Pirrone and Keating, 2010; Lin et al., 2006).

Dry deposition of $\mathrm{Hg}(0), \mathrm{Hg}(\mathrm{II})$ and $\mathrm{Hg}(\mathrm{P})$ is accounted for in the GNAQPMS-Hg model and simulated with the Wesely (1989) resistance model, which considers the effect of different land cover types and characterizes the diurnal variation of dry deposition velocities. Henry's law constant for $\mathrm{Hg}(0)$ is set to $0.11 \mathrm{M} \mathrm{atm}^{-1}$ (Lin and Pehkonen, 1999) with a temperature factor of $-4970 \mathrm{~K}$ (Clever et al., 1985), and the surface reactivity is set to zero. $\mathrm{Hg}$ (II) represents $\mathrm{HgCl}_{2}$ and $\mathrm{Hg}(\mathrm{OH})_{2}$. Henry's law constant is assumed to be the same as $\mathrm{HNO}_{3}$ because they have similar solubility (Bullock and Brehme, 2002). Like $\mathrm{HNO}_{3}, \mathrm{Hg}(\mathrm{II})$ has a strong tendency to stick to surfaces and its dry deposition occurs readily, so the surface resistance for $\mathrm{Hg}$ (II) in the dry deposition scheme is set to zero. The $\operatorname{Hg}(\mathrm{P})$ dry deposition velocity is set equal to that for sulfate, similar to that applied in the CMAQ-Hg and STEM-Hg models (Bullock and Brehme, 2002; Pan et al., 2008). A more detailed description of the dry deposition scheme used in the model is given in Sect. S2.1 in the Supplement. Model intercomparison studies demonstrate that there are still very large uncertainties in Hg dry deposition estimates (Bullock et al., 2008), and this can be ascribed to the wide range of treatments and physical parameters for dry deposition used in different models.

The wet deposition of $\mathrm{Hg}$ includes in-cloud and belowcloud scavenging. In-cloud scavenging is dependent on cloud and rain water content, species solubility and chemical transformation in the liquid phase, while below-cloud scavenging depends mainly on total rainfall intensity and washout effi- ciency. Among the three forms of mercury, wet deposition of $\mathrm{Hg}(0)$ is minor compared to $\mathrm{Hg}(\mathrm{II})$ and $\mathrm{Hg}(\mathrm{P})$ due to its low solubility. Therefore, $\mathrm{Hg}(0)$ oxidation will enhance total $\mathrm{Hg}$ wet deposition. In the GNAQPMS-Hg model, wet deposition of $\mathrm{Hg}$ species is calculated through adapting the RADM mechanism. The physical properties (e.g., Henry's law constant, surface reactivity, molecular diffusivity) used are the same as those in the dry deposition module. A more detailed description of the wet deposition scheme used in the model is given in Sect. S2.2 in the Supplement. Currently, the uncertainties of $\mathrm{Hg}$ wet deposition simulation are mainly from the assumptions made in the cloud scavenging process and the uncertainty associated with the precipitation fields (Seigneur et al., 2001; Lin et al., 2006).

\subsection{Mercury emissions}

We include anthropogenic emissions, biomass burning emissions, geogenic emissions, land re-emission and ocean emissions (including re-emission) of $\mathrm{Hg}$ in the model. Emissions from artisanal mining and volcanoes are neglected due to lack of fundamental data. The former is estimated to be $400 \mathrm{Mg} \mathrm{yr}^{-1}$ and the latter $90 \mathrm{Mg} \mathrm{yr}^{-1}$, and they account for about 5 and $1 \%$ of global total $\mathrm{Hg}$ emissions (Pirrone et al., 2010). Note that biomass burning emissions, geogenic emissions, land and ocean emissions are all treated as $\mathrm{Hg}(0)$. Global $\mathrm{Hg}$ emissions in the model are compared to previous studies in Table 2, and their spatial distributions are given in Figs. S4-S6 in the Supplement.

Anthropogenic emissions in 2000 are derived from the Arctic Monitoring and Assessment Programme (AMAP) inventory (Pacyna et al., 2006; Wilson et al., 2006). This inventory has a horizontal resolution of $0.5^{\circ} \times 0.5^{\circ}$ and no seasonal variation. Following Selin et al. (2008), we increase the Asian $\left(0-60^{\circ} \mathrm{N}, 65-150^{\circ} \mathrm{E}\right) \mathrm{Hg}(0)$ emissions in the AMAP inventory by $50 \%$ (about $300 \mathrm{Mg} \mathrm{yr}^{-1}$ ) to account for the regional underestimation identified by Jaffe et al. (2005). The modified inventory has a total emission of $2488 \mathrm{Mg} \mathrm{yr}^{-1}$, with $\mathrm{Hg}(0), \mathrm{Hg}(\mathrm{II})$ and $\mathrm{Hg}(\mathrm{P})$ accounting for 63,29 and $8 \%$, respectively. The major source regions are Asia and Africa, accounting for $59 \%\left(1480 \mathrm{Mg} \mathrm{yr}^{-1}\right)$ and $16 \%\left(399 \mathrm{Mg} \mathrm{yr}^{-1}\right)$, while Europe and North America contribute only 7 and $6 \%$. China has the largest emissions at country level (about $785 \mathrm{Mg} \mathrm{yr}^{-1}$ ), contributing $53 \%$ and $32 \%$ to the Asian and global anthropogenic Hg emissions, respectively. It is noted that the emissions over South Africa in this inventory were reported to be flawed (AMAP/UNEP, 2008) and much higher than reality. The effects of these flawed emissions on the simulated results are assessed in Section S3 in the Supplement.

Biomass burning emissions are specified by mapping an annual mean value of $675 \mathrm{Mg} \mathrm{yr}^{-1}$ (Friedli et al., 2009) to the spatial and temporal distribution of $\mathrm{CO}$ biomass burning emissions from the IPCC-AR5 (Intergovernmental Panel on Climate Change Fifth Assessment Report) emissions inven- 
Table 2. Global budgets of TGM in the literature (in $\mathrm{Mg} \mathrm{yr}^{-1}$ ).

\begin{tabular}{lrrrrrrrr}
\hline & $\begin{array}{r}\text { Bergan et } \\
\text { al. (1999) }\end{array}$ & $\begin{array}{r}\text { Shia et } \\
\text { al. (1999) }\end{array}$ & $\begin{array}{r}\text { Lamborg et } \\
\text { al. (2002) }\end{array}$ & $\begin{array}{r}\text { Mason et } \\
\text { al. (2002) }\end{array}$ & $\begin{array}{r}\text { Seigneur et } \\
\text { al. (2004) }\end{array}$ & $\begin{array}{r}\text { Selin et } \\
\text { al. (2007) }\end{array}$ & $\begin{array}{r}\text { Selin et } \\
\text { al. (2008) }\end{array}$ & $\begin{array}{r}\text { This } \\
\text { work }\end{array}$ \\
\hline Total Sources & 6050 & 6100 & 4400 & 6600 & 6411 & 7000 & 11200 & 10163 \\
Anthropogenic & 2150 & 2100 & 2600 & 2400 & 2143 & 2200 & 3400 & 2488 \\
Land & 2500 & 2000 & 1000 & 1600 & 2290 & 2000 & 2800 & 2675 \\
Ocean & 1400 & 2000 & 800 & 2600 & 1978 & 2800 & 5000 & 5000 \\
Total Sinks & 6050 & 6100 & 4200 & 6600 & 6411 & 7000 & 11200 & 10163 \\
Wet deposition & & 2800 & & 3920 & & 2100 & 2283 \\
Dry deposition & & 3300 & & 2680 & & 4700 & 580 \\
TGM Burden & 6050 & 10400 & 5220 & 5000 & 7690 & 5360 & 5600 & 5507 \\
TGM lifetime (yr) & 1 & 1.7 & 1.3 & 0.76 & 1.2 & 0.79 & 0.5 & 0.54 \\
\hline
\end{tabular}

tory (Lamarque et al., 2010). The regional and monthly emission amounts are prescribed based on Friedli et al. (2009). A similar method has been used by Jung et al. (2009).

The geogenic emissions here represent mobilization of $\mathrm{Hg}$ by degassing from geological reservoirs. Following Selin et al. (2007), we consider a geogenic source of $500 \mathrm{Mg} \mathrm{yr}^{-1}$ distributed according to the locations of $\mathrm{Hg}$ mines (Frank, 1999) as an indicator of $\mathrm{Hg}$ deposits. No temporal variation is applied to the geogenic emissions.

Land and ocean emissions are not dynamically calculated in the model due to the large uncertainties associated with current parameterizations. Consistent with several previous studies (Selin et al., 2007; Seigneur et al., 2001), the global annual land re-emission of $\mathrm{Hg}$ is assumed to be $1500 \mathrm{Mg} \mathrm{yr}^{-1}$. The biogenic $\mathrm{CO}$ emissions from the Global Emission InitiAtive (GEIA) inventory (Guenther et al., 2006) are used as spatial and temporal surrogates to map the land re-emission. Regional emission totals from different latitude zones and land uses are prescribed based on Mason (2009).

Ocean emissions in our model are specified as $5000 \mathrm{Mg} \mathrm{yr}^{-1}$ (including re-emission), close to the estimates of Selin et al. (2008). Similarly, ocean emissions are mapped according to the distribution of ocean biogenic $\mathrm{CO}$ emissions from the Precursors of Ozone and their Effects in the Troposphere (POET) inventory (Granier et al., 2005). Additionally, ocean emissions are adjusted to reflect several distribution characteristics: (1) ocean emissions are high in summer but low in winter (Strode et al., 2007), (2) ocean emissions are largest in the tropics and downwind of industrial regions (Strode et al., 2007; Soerensen et al., 2010b), and (3) ocean emissions are large at mid and high latitudes in the Southern Hemisphere due to high wind speeds (Selin et al., 2008).

\subsection{Model setup}

Two nested domains covering the whole globe and East Asia are configured in this study. The horizontal resolutions are $1^{\circ} \times 1^{\circ}$ and $0.33^{\circ} \times 0.33^{\circ}$, respectively. Vertically, the model uses 20 terrain-following layers from the sur- face to $20 \mathrm{~km}$ a.s.l., with a decreasing resolution with height. Roughly, the lowest 14-18 layers are in the troposphere and the remaining layers are in the stratosphere. The time step in the model calculation is $600 \mathrm{~s}$. The input/output frequency is $6 \mathrm{~h}$ in the global domain but $3 \mathrm{~h}$ in the nested domain. The meteorological fields are provided by the global version of the Weather Research and Forecasting (WRF) model. The atmospheric lifetime of $\mathrm{Hg}(0)$ is $0.5-2$ years (Schroeder and Munthe, 1998), so to ensure mixing through the global troposphere and approach steady state we conduct the simulation for a 4-year period, with the first 3 years used for initialization and the last year (2001) used for analyses.

Emissions of reactive gases and aerosols used in this study are from several databases: (1) the IPCC-AR5 anthropogenic and biomass burning emissions for 2000 (Lamarque et al., 2010); (2) the GEIA biogenic emissions for 2000 (Guenther et al., 2006) and lightning emissions of nitric oxide $\left(\mathrm{NO}_{x}\right)$ for 1983-1990 (Price et al., 1997); (3) the POET ocean emissions of volatile organic compounds (VOCs) for 2000 (Granier et al., 2005); and (4) the soil $\mathrm{NO}_{x}$ emissions for 2001 from Yan et al. (2005). All emissions are interpolated and remapped to match the model grids of the global and nested domains. The initial and top boundary conditions for $\mathrm{O}_{3}, \mathrm{NO}_{x}$, and $\mathrm{CO}$ are taken from a global chemical transport model (MOZART-V2.4) with $2.8^{\circ}$ resolution (Horowitz et al., 2003).

Two model simulations, with and without Chinese primary anthropogenic $\mathrm{Hg}$ emissions, are carried out in this study. The differences between the two simulations are attributed to the influence of Chinese primary anthropogenic Hg emissions.

\section{Model evaluation}

\subsection{Observational data}

Compared to reactive gases and aerosols, atmospheric $\mathrm{Hg}$ measurements are still quite sparse. Routine monitoring networks for atmospheric $\mathrm{Hg}$ concentrations and deposition 
have only been established in Europe and North America. Lack of $\mathrm{Hg}$ observational data is a great restriction against advancing our understanding of global $\mathrm{Hg}$ cycling and improving our skill in modeling. There is an urgent need to establish a coordinated global $\mathrm{Hg}$ monitoring network for current Hg study (Sprovieri et al., 2010; Keeler et al., 2009).

The observational data set in this study is based partly on the database shared by the GEOS-Chem $\mathrm{Hg}$ modeling group (public access at https://github.com/GC-Hg/HgBenchmark; Selin et al., 2007, 2008; Holmes et al., 2010). This is supplemented with scattered $\mathrm{Hg}$ observations across East Asia collected from the literature. The observations used in this study are summarized as follows: (1) long-term TGM/GEM (gaseous elemental mercury) measurements at 51 land sites, with 49 in the Northern Hemisphere and 2 in the Southern Hemisphere; (2) long-term RGM/TPM measurements at 26 land sites, all in the Northern Hemisphere; (3) short-term $\mathrm{Hg}$ species measurements from six ship cruises; (4) wet deposition measurements from the MDN (the Mercury Deposition Network in North America, http://nadp.sws.uiuc. edu/nadpdata/mdnalldata.asp) and EMEP (the European Monitoring and Evaluation Programme, http://www.nilu.no/ projects/ccc/emepdata.html) monitoring networks, with 51 and 8 sites, respectively; (5) dry and wet deposition measurements at 19 sites in East Asia. Further information about the measurement sites and data sources is given in Tables S2S5 in the Supplement. It should be noted that the time periods of the measurements do not all match with those of the simulation, and this difference may partially explain any model-observation discrepancies. The influence of the mismatch of time periods when comparing the simulated results with the observations was qualitatively analyzed and shown in Sect. S4.1 in the Supplement.

\subsection{Global mercury budget}

Figure 2 gives the global mercury budget in GNAQPMS$\mathrm{Hg}$, including the cycling among atmosphere, ocean and land. The total atmospheric burden of $\mathrm{Hg}$ is $5546 \mathrm{Mg}$, with $\mathrm{Hg}(0), \mathrm{Hg}(\mathrm{II})$, and $\mathrm{Hg}(\mathrm{P})$ contributing 90,9 and $1 \%$, respectively. Therefore, mercury in the atmosphere exists mainly as $\mathrm{Hg}(0)$. Total emissions and deposition of $\mathrm{Hg}$ are 5163 and $2866 \mathrm{Mg} \mathrm{yr}^{-1}$ over land (a net source), and 5000 and $7297 \mathrm{Mg} \mathrm{yr}^{-1}$ over ocean (a net sink), indicating that $\mathrm{Hg}$ is transported from land to ocean. For total deposition of $\mathrm{Hg}$ species, $\mathrm{Hg}(0)$ and $\mathrm{Hg}(\mathrm{II}) / \mathrm{Hg}(\mathrm{P})$ account for 38 and $62 \%$ over Earth's surface. Over land, deposition of $\mathrm{Hg}(\mathrm{II}) / \mathrm{Hg}(\mathrm{P})$ is more prominent than that of $\mathrm{Hg}(0)$, while they are both important over the ocean. Our results for total $\mathrm{Hg}$ deposition over ocean and $\mathrm{Hg}(\mathrm{II}) / \mathrm{Hg}(\mathrm{P})$ deposition over land are very close to that of GEOS-Chem (Selin et al., 2008). However, $\mathrm{Hg}(0)$ deposition over land derived from GNAQPMS-Hg is much smaller. This may be due to the lower reactivity coefficient used in the dry deposition module in GNAQPMS-Hg

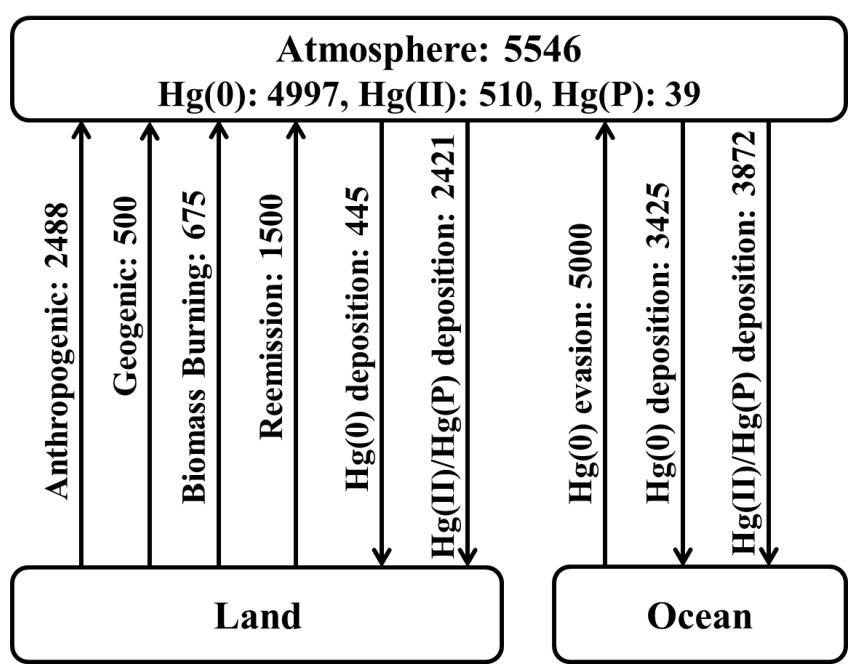

Figure 2. Global atmospheric mercury budget in GNAQPMS-Hg (in $\mathrm{Mg} \mathrm{yr}^{-1}$ ).

(zero in GNAQPMS-Hg but $10^{-5}$ in GEOS-Chem), which produces a lower dry deposition velocity for $\mathrm{Hg}(0)$.

Table 2 compares the GNAQPMS-Hg TGM budget and lifetime to those from previous modeling studies. The TGM sources, sinks, burden and lifetime estimated from GNAQPMS-Hg are all in the range determined by previous studies. Taking the TGM lifetime as an example, the reported range is $0.5-1.7$ years and it is 0.54 years for GNAPQMS$\mathrm{Hg}$. In addition, similar to the results of GEOS-Chem (Selin et al., 2007) and CAM-Chem-Hg (Lei et al., 2013), Hg dry deposition in GNAQPMS-Hg dominates globally over wet deposition. Dry and wet deposition account for 78 and $22 \%$, respectively.

\subsection{Total gaseous mercury (TGM)}

As shown in Fig. 3, the main characteristics of the spatial distribution of TGM are captured well by the model. High surface TGM concentrations are found in or downwind of areas with intensive mercury-related mining (e.g., western USA) and rapid industrialization (e.g., East Asia). In particular, TGM concentrations even exceed $3 \mathrm{ng} \mathrm{m}^{-3}$ in eastern China. Both model simulations and observations show a significant surface interhemispheric gradient in TGM (Figs. 3, 4). Based on background observations, Lindberg et al. (2007) reported that mean $\operatorname{Hg}(0)$ concentrations were $1.5-1.7 \mathrm{ng} \mathrm{m}^{-3}$ in the Northern Hemisphere and $1.1-1.7 \mathrm{ng} \mathrm{m}^{-3}$ in the Southern Hemisphere. Lamborg et al. (2002) also estimated the range of north-south interhemispheric TGM concentration ratios for surface air as 1.2-1.8. Our model results share a general similarity with these studies. In GNAQPMS-Hg, surface mean TGM concentrations in the Northern Hemisphere and Southern Hemisphere are 1.56 and $1.23 \mathrm{ng} \mathrm{m}^{-3}$, and the derived interhemispheric ratio is 1.27 . However, it should 

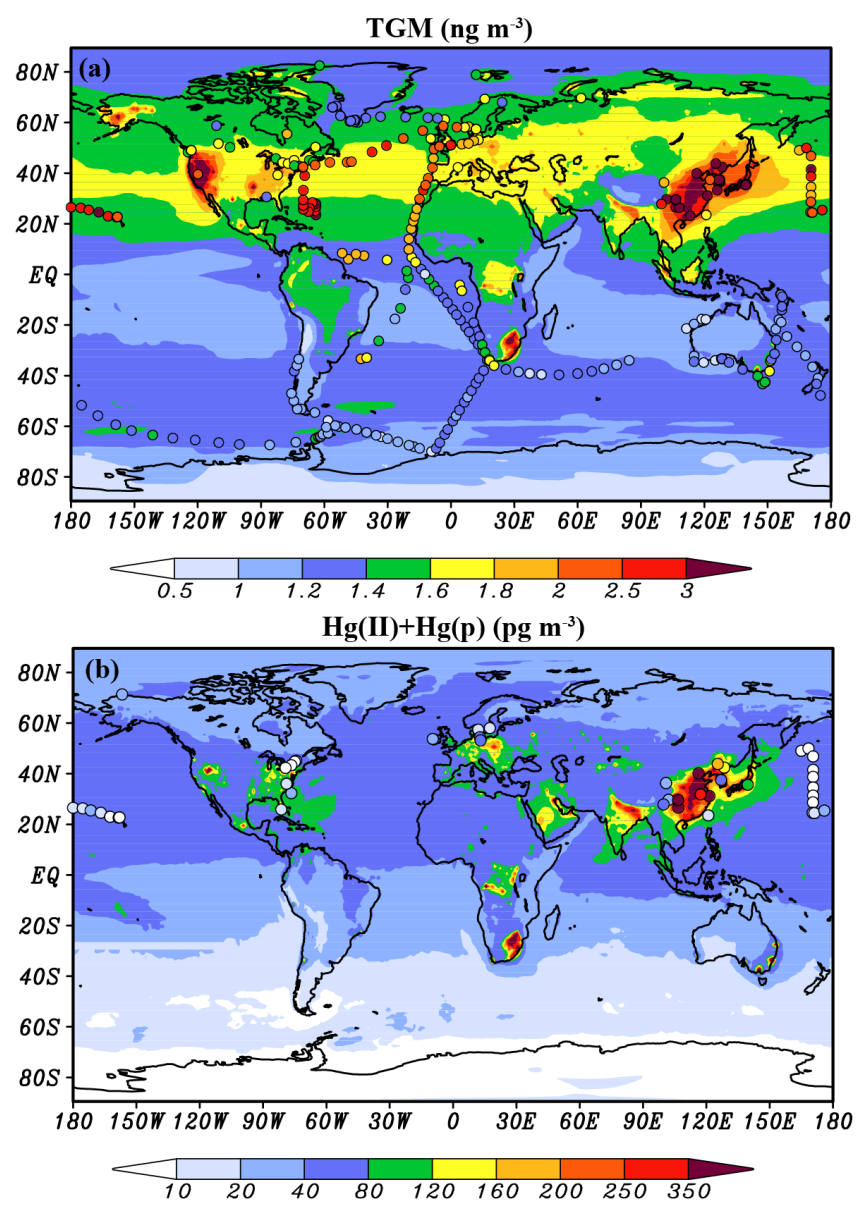

Figure 3. Annual average TGM (a) and oxidized mercury $\mathrm{Hg}(\mathrm{II})+\mathrm{Hg}(\mathrm{P})$ (b) concentrations in surface air. Model results (background, for year 2001) are compared to observations (circles) from long-term surface sites and short-term ship cruises. Units of TGM and oxidized mercury are nanograms per cubic meter $\left(\mathrm{ng} \mathrm{m}^{-3}\right)$ and picograms per cubic meter $\left(\mathrm{pg} \mathrm{m}^{-3}\right)$, respectively.

be noted that GNAQPMS-Hg is systematically biased low relative to cruise observations in the Northern Hemisphere, which leads to underestimation of the TGM interhemispheric ratio compared with the range $(1.49 \pm 0.12)$ reported by Temme et al. (2003) based on observations from several Atlantic cruises. This disagreement was also found by several previous modeling studies (Seigneur et al., 2004; Selin et al., 2007) and can be attributed to the inability of current models to reproduce the air-sea exchange of $\mathrm{Hg}$ reasonably (Soerensen et al., 2010a). More specifically, this discrepancy is due to upwelling mercury from the subsurface ocean, possibly reflecting the legacy of past anthropogenic emissions (Holmes et al., 2010), and has been partially demonstrated by Soerensen et al. (2012). In general, the simulated TGM concentrations match observations within a factor of 2 (Fig. 10). The correlation coefficient $(R)$ and normalized mean bias (NMB) between model results and observations from 51 land sites are 0.7 and $-18 \%$, respectively (Table 3 ).

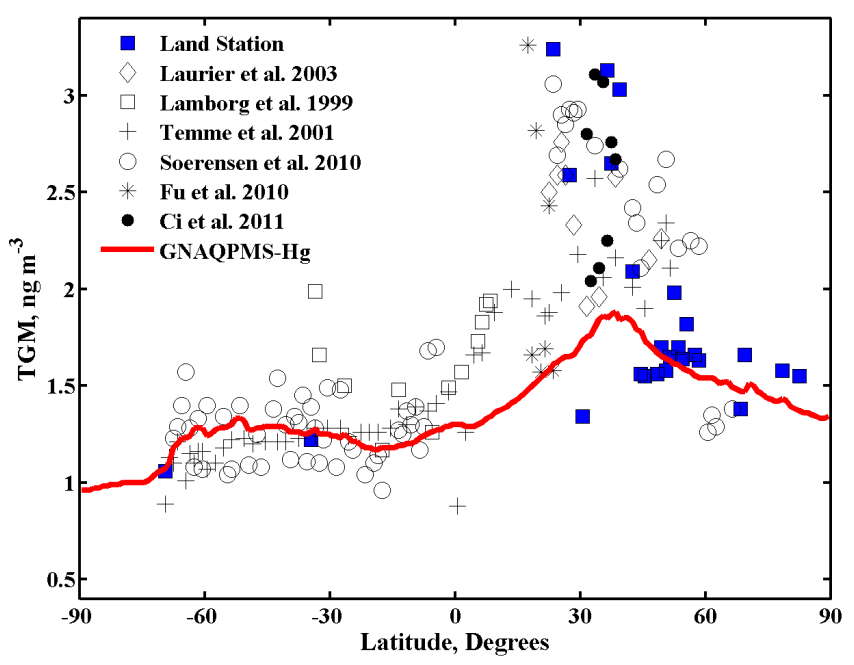

Figure 4. Variation of surface TGM concentrations $\left(\mathrm{ng} \mathrm{m}^{-3}\right)$ with latitude. Zonally averaged, annual mean model results (line) are compared to observations (symbols).

Figure 5 illustrates the mean seasonal variations of surface TGM concentrations in North America, Europe, East Asia, the Arctic, the Antarctic (Neumayer) and South Africa (Cape Point). In northern midlatitudes, TGM concentrations are high in winter but low in summer. This seasonality can be reproduced well by GNAQPMS-Hg. The summer low is caused by high $\mathrm{OH}$ concentrations and frequent precipitation (Bergan and Rodhe, 2001). Compared with observations, the simulated TGM monthly variations are stronger in North America but weaker in East Asia. The site by site comparisons in East Asia are shown in Fig. S9 in the Supplement. We can see that the nested simulation can improve model performance well for simulating TGM monthly variations in East Asia. At Arctic and Antarctic sites, TGM shows a spring minimum driven by MDEs and a summer maximum driven by re-emission from the snowpack (Steffen et al., 2005). The summer maximum is captured by GNAQPMS-Hg because high re-emission in polar summer has been taken into account in our land re-emission inventories. However, due to missing halogen chemistry, the model fails to reproduce the spring minimum. At Cape Point, both observed and simulated TGM show little seasonal variation. However, simulated monthly TGM concentrations are systematically biased high (NMB is $87 \%$ ), which can be attributed to the flawed anthropogenic emissions in the AMAP emission inventories over South Africa (AMAP/UNEP, 2008). By updating the anthropogenic emissions over South Africa, the simulated TGM concentrations at Cape Point decrease from 1.77 to $1.23 \mathrm{ng} \mathrm{m}^{-3}$, more close to the observed values (See Sect. S3 in the Supplement).

An additional evaluation and analyses of simulated diurnal and vertical variation of TGM concentrations are given in Sect. S4.2 in the Supplement. 


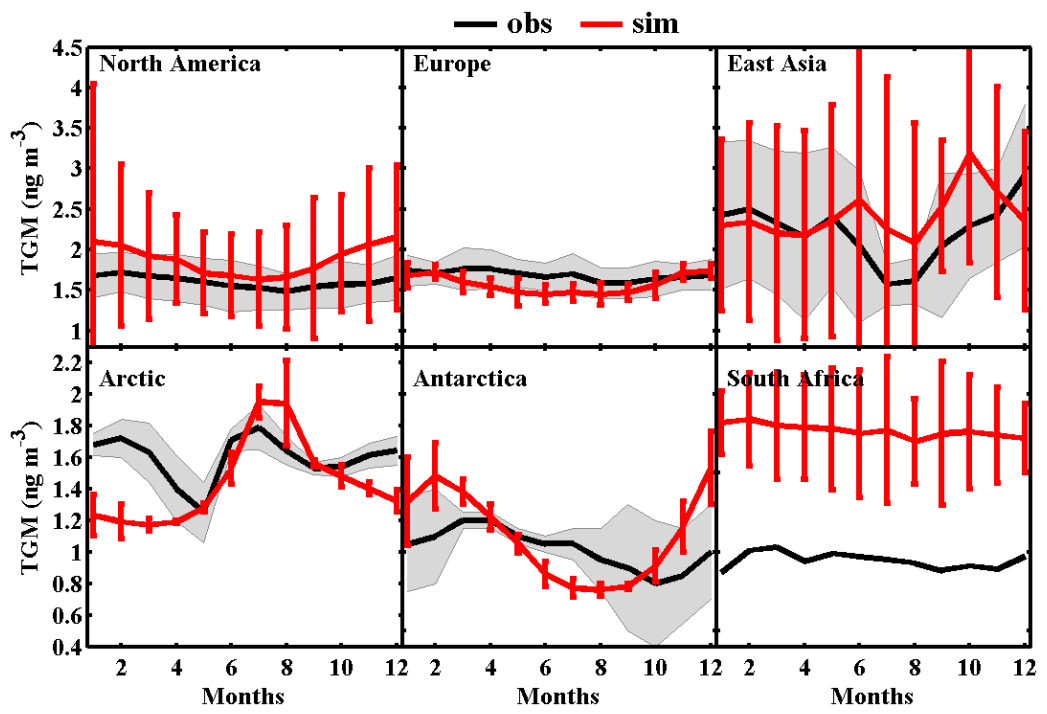

Figure 5. Mean seasonal variation of TGM $\left(\mathrm{ng} \mathrm{m}^{-3}\right)$ over North America, Europe, East Asia, the Arctic, Antarctica and South Africa sites. Gray shaded areas and red vertical bars show 1 standard deviation over the sites for observations and for model results.

\subsection{Oxidized mercury}

Figure 3 also shows the global distribution of oxidized mercury (defined as the sum of RGM+TPM in the observations and $\mathrm{Hg}(\mathrm{II})+\mathrm{Hg}(\mathrm{P})$ in the model). Similar to TGM, a pronounced north-south interhemispheric gradient is found for surface concentrations of oxidized mercury, which is consistent with the global distribution of emissions. Both the model simulation and observations indicate that oxidized mercury concentrations are much higher in East Asia than North America and Europe. Compared to scarce available observations, oxidized mercury concentrations are overestimated by GNAQPMS-Hg in most parts of the world (except East Asia). This discrepancy may partially be attributed to excessive oxidation of $\mathrm{Hg}(0)$ by relatively high concentrations of $\mathrm{OH}$ and $\mathrm{O}_{3}$ (especially over the ocean) and uncertainties concerning $\mathrm{Hg}$ chemical speciation in emission inventories. The simulated tropospheric mean $\mathrm{OH}$ concentration is $1.41 \times 10^{6}$ molec $\mathrm{cm}^{-3}$. This is at the high end of the concentration range $\left(0.65-1.56 \times 10^{6} \mathrm{molec} \mathrm{cm}^{-3}\right)$ summarized by Lawrence et al. (2001) and is about $27 \%$ higher than the ensemble mean $\left(11.1 \pm 1.8 \times 10^{5}\right.$ molec cm$\left.^{-3}\right)$ of the Atmospheric Chemistry and Climate Model Intercomparison Project (ACCMIP) models (Voulgarakis et al., 2013). The simulated mean surface $\mathrm{O}_{3}$ in the North Pacific and North Atlantic is overestimated by 27 and $34 \%$ compared to observations from the WDCGG (World Data Centre for Greenhouse Gases) network, although concentrations over land are reproduced relatively well (see Figs. S10 and S11 in the Supplement). Moreover, uncertainties of $\mathrm{Hg}$ chemistry (e.g., gasparticle partitioning of RGM, in-plume reduction of RGM) and deposition processes in the present model might also contribute to this discrepancy. Overall, the simulated oxi- dized mercury concentrations agree with observations within a factor of 5 (Fig. 10). The statistical indicators $R$ and NMB, calculated from 26 land sites, are 0.53 and $3 \%$ (Table 3), respectively.

\subsection{Wet deposition}

Wet deposition is mainly determined by the distribution of precipitation and $\mathrm{Hg}$ concentrations. Figures 6 and 7 evaluate the simulated annual $\mathrm{Hg}$ wet deposition and accumulated precipitation over North America, Europe and East Asia. In general, GNAQPMS-Hg reproduces the spatial patterns of $\mathrm{Hg}$ wet deposition relatively well.

Over North America, the maximum wet deposition occurs in the southeast, corresponding to high $\mathrm{OH}$ concentrations and frequent precipitation there, while less wet deposition occurs in the west and north, where there is much less precipitation. GNAQPMS-Hg predicts the magnitude of mean wet deposition within $5 \%$ and shows a good spatial correlation $(R=0.76)$ (Table 3$)$. These results are similar to those of GEOS-Chem (Selin et al., 2007). However, it should be also noted that precipitation in the southeast is slightly overestimated by the model.

Over Europe, model performance for wet deposition and precipitation are better than over North America and East Asia. High spatial correlation between the simulated and observed results are found for both wet deposition $(R=0.78)$ and precipitation $(R=0.86)$, and the NMBs are both less than $5 \%$ (Table 3 ).

Over East Asia, $\mathrm{Hg}$ wet deposition is not only related to the precipitation pattern but also the local $\mathrm{Hg}$ emissions, especially in southwestern China, in the Jilin province of China, and in central Japan. Model performance for wet 
Table 3. Statistical summary of comparisons of the model results with observations ${ }^{\mathrm{a}}$.

\begin{tabular}{llrrrr}
\hline Parameter & Region & $R$ & NMB & RMSE & SVR $^{\mathrm{b}}$ \\
\hline \multirow{4}{*}{ TGM } & East Asia nested & 0.51 & $-39 \%$ & 3.87 & 2.56 \\
& East Asia & 0.54 & $-32 \%$ & 3.61 & 2.56 \\
& North America & 0.69 & $18 \%$ & 0.58 & 0.48 \\
& Europe & 0.57 & $-8 \%$ & 0.17 & 0.35 \\
& Global & 0.70 & $-18 \%$ & 2.22 & - \\
\hline \multirow{5}{*}{ Oxidized mercury } & East Asia nested & 0.45 & $-12 \%$ & 242 & 3.66 \\
& East Asia & 0.31 & $-10 \%$ & 259 & 3.66 \\
& North America & 0.53 & $148 \%$ & 28 & 1.61 \\
& Europe & 0.91 & $155 \%$ & 48 & 1.00 \\
& Global & 0.53 & $3 \%$ & 185 & - \\
\hline \multirow{5}{*}{ Wet deposition } & East Asia nested & 0.78 & $-28 \%$ & 45.5 & 6.69 \\
& East Asia & 0.36 & $-61 \%$ & 60.1 & 6.69 \\
& North America & 0.76 & $-4 \%$ & 4.3 & 1.89 \\
& Europe & 0.78 & $4 \%$ & 1.5 & 1.40 \\
& Global & 0.38 & $-36 \%$ & 29.3 & - \\
\hline \multirow{2}{*}{ Dry deposition } & East Asia nested & 0.88 & $-42 \%$ & 87.0 & - \\
& East Asia & 0.81 & $-42 \%$ & 88.5 & - \\
\hline
\end{tabular}

${ }^{a} R$, NMB, RMSE, and SVR represent correlation coefficient, normalized mean bias, root mean square error, and spatial variation ratio. Units of TGM, oxidized mercury, wet and dry deposition are $\mathrm{ng} \mathrm{m}^{-3}, \mathrm{pg} \mathrm{m}^{-3}, \mu \mathrm{g} \mathrm{m}^{-2} \mathrm{yr}^{-1}, \mu \mathrm{g} \mathrm{m}^{-2} \mathrm{yr}^{-1}$, respectively. ${ }^{\mathrm{b}} \mathrm{SVR}$ is defined as (max-min)/mean observations over all sites.

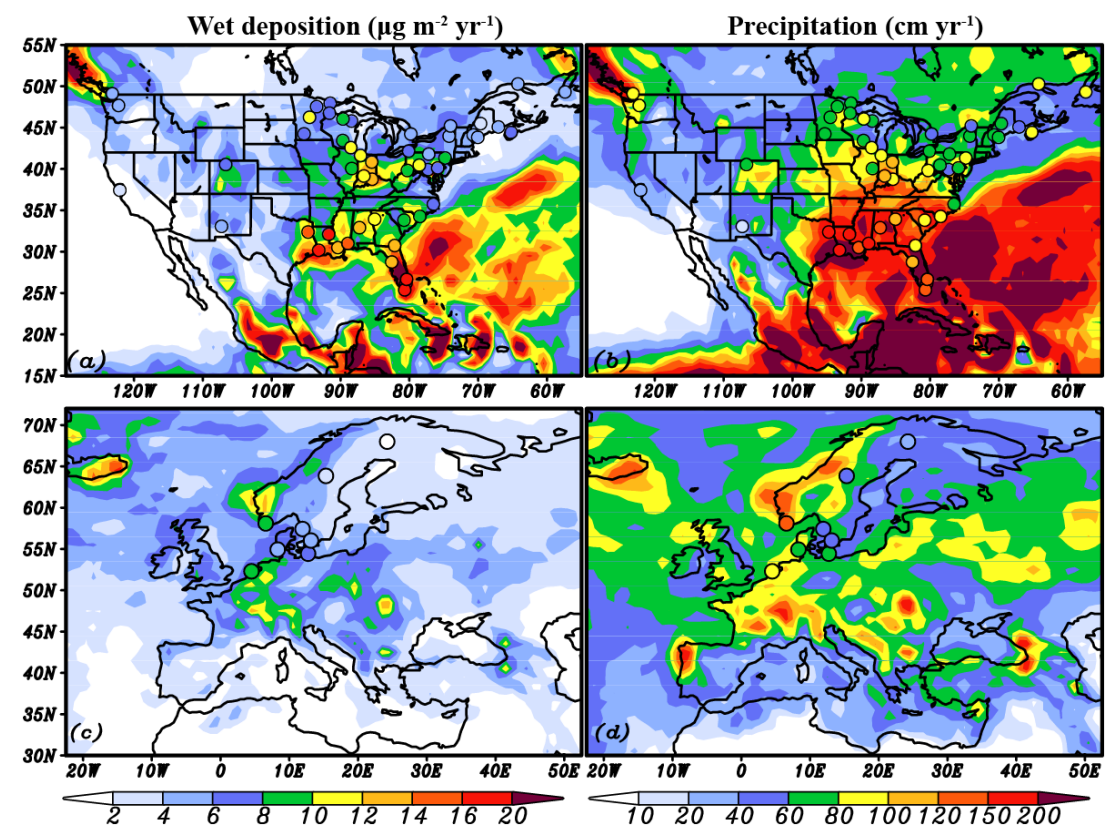

Figure 6. Simulated annual mercury wet deposition $\left(\mu \mathrm{g} \mathrm{m}^{-2} \mathrm{yr}^{-1}\right)$ and accumulated precipitation $\left(\mathrm{cm} \mathrm{yr}^{-1}\right)$ over North America $(\mathbf{a}, \mathbf{b})$ and Europe (c, d) in 2001. Overlaid points show observations for the same year from the Mercury Deposition Network (MDN) over North America, and the European Monitoring and Evaluation Programme (EMEP) over Europe.

deposition over East Asia is poorer than over Europe and North America. Although the spatial distribution and magnitude of precipitation over East Asia are seemingly well reproduced $(R=0.64$ and $\mathrm{NMB}=-6 \%)$, a large underes- timation (NMB $=-61 \%$ ) of wet deposition is found here. Specifically, this is because the model fails to capture the high wet deposition at certain sites. For example, the observed wet deposition over Shanghai and Changchun are 251 

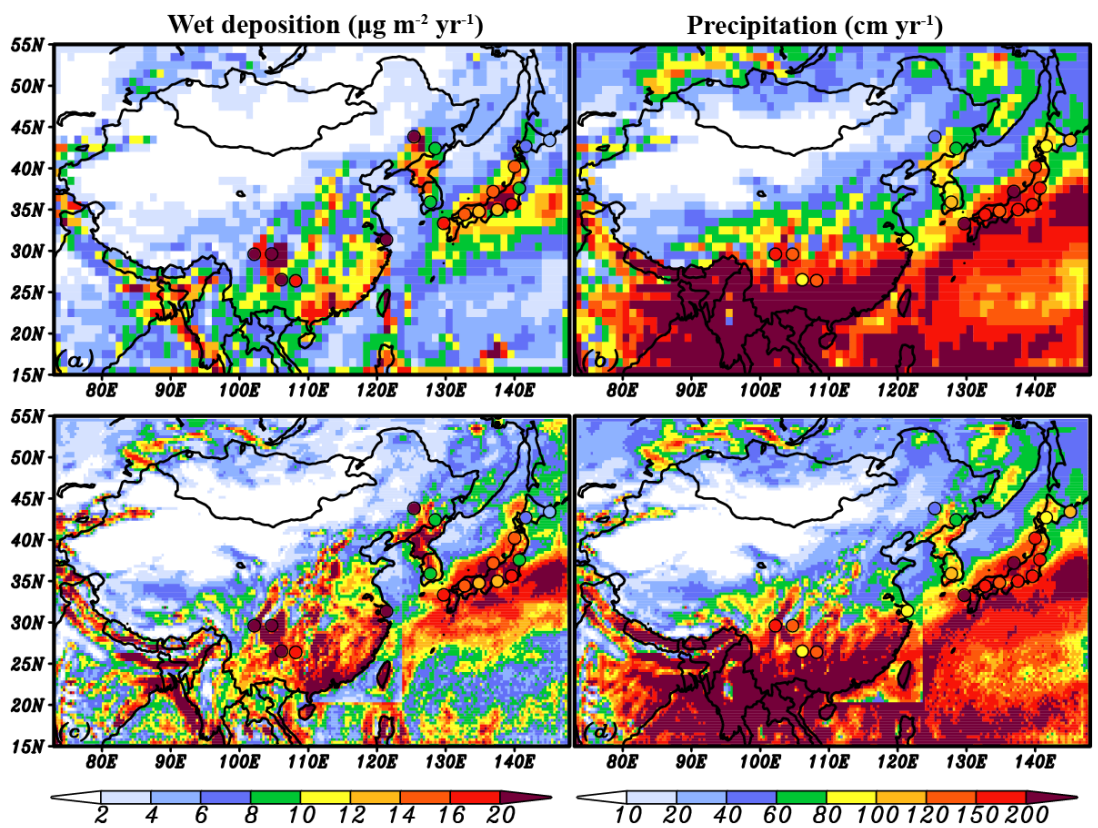

Figure 7. Simulated annual mercury wet deposition $\left(\mu \mathrm{g} \mathrm{m}^{-2} \mathrm{yr}^{-1}\right)$ and accumulated precipitation $\left(\mathrm{cm} \mathrm{yr}^{-1}\right)$ over East Asia in the global (a, b) and nested (c, d) domains in 2001. Overlaid points show observations collected from the literature. Note that observations and simulated results are not in the same year

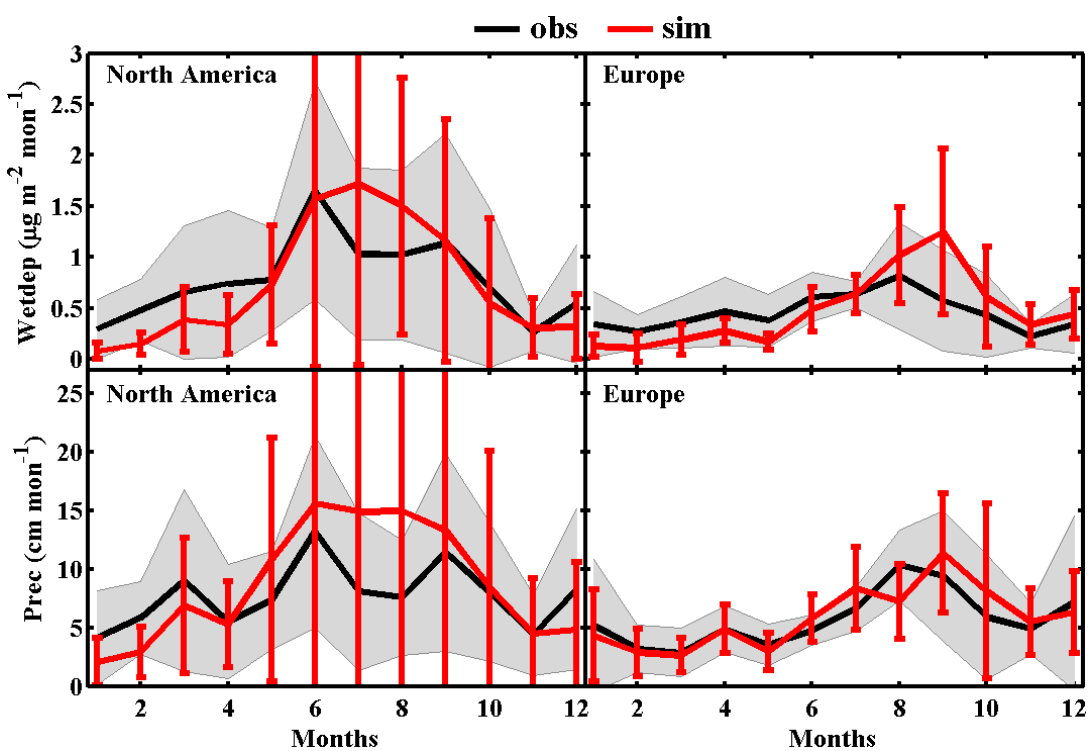

Figure 8. Mean seasonal variation of mercury wet deposition $\left(\mu \mathrm{g} \mathrm{m}^{-2} \mathrm{mon}^{-1}\right)$ and accumulated precipitation $\left(\mathrm{cm} \mathrm{mon}^{-1}\right)$ at North America (51 sites averaged) and Europe (8 sites averaged) sites in 2001. Gray shaded areas and red vertical bars show 1 standard deviation over the sites for observations and for model results.

and $108 \mu \mathrm{g} \mathrm{m}^{-2} \mathrm{yr}^{-1}$ while the corresponding simulated values are only 25 and $13 \mu \mathrm{g} \mathrm{m}^{-2} \mathrm{yr}^{-1}$. This suggests that it is hard for models with coarse horizontal resolution to characterize the high local mercury pollution in China. The difference between the simulated and observed time periods and uncertainties in the emission inventories may also contribute to these discrepancies.
Figure 8 further compares the simulated seasonal cycle of wet deposition with measurements at MDN sites over North America and EMEP sites over Europe. No monthly wet deposition observations are available over East Asia. Wet deposition and precipitation share similar monthly variations, with high values in summer and autumn and low values in winter, as shown by both observations and simula- 
tion. In summer and autumn, the variation in wet deposition and precipitation among sites is larger than for other seasons, and this is evident from the greater variability in Fig. 8. GNAQPMS-Hg tends to overestimate wet deposition and precipitation in July and August over North America.

\subsection{Dry deposition}

Due to limited observations, only Hg dry deposition over East Asia is evaluated in this study. It should be noted that data (Table S5 in the Supplement) used to evaluate the model simulation of dry deposition is not directly measured but is inferred or estimated based on measurements of total $\mathrm{Hg}$ in throughfall and rainwater, wet deposition and atmospheric concentrations. Associated with local $\mathrm{Hg}$ emissions, high dry deposition mainly occurs over central eastern China and central Japan (Fig. 9). The modeled dry deposition has a good spatial correlation with observations $(r=0.81)$, but there is a substantial negative bias ( $\mathrm{NMB}=-42 \%$, Table 3$)$. In general, the simulated dry deposition agrees with observations within a factor of 5 (Fig. 10). Over Japan, the model results are biased high by a factor of $2-5$, which may be caused by overestimation of $\mathrm{Hg}(\mathrm{II})$ and $\mathrm{Hg}(\mathrm{P})$ emissions and a missing model mechanism to deal with fast in-plume reduction of $\mathrm{Hg}$ (II) (Vijayaraghavan et al., 2008; Amos et al., 2012; Zhang et al., 2012). Taking Tokyo as an example, observed $\mathrm{Hg}(\mathrm{P})$ is only $98 \mathrm{pg} \mathrm{m}^{-3}$ while the simulated value is as high as $648 \mathrm{pg} \mathrm{m}^{-3}$. Modeling studies conducted by Pan et al. (2008) using the STEM-Hg model also found large overestimation of dry deposition over Japan. Conversely, the model results are biased low by a factor of $2-5$ over China, which indicates probable underestimation of Chinese $\mathrm{Hg}$ emissions.

\subsection{Model performance summary and comparison}

In this section, we summarize the statistical performance of GNAQPMS-Hg for TGM, oxidized mercury, and wet and dry deposition, compare the model performance over East Asia, North America and Europe, and assess the effects of horizontal resolution on model predictions over East Asia. As shown in Fig. 10, the simulated TGM and wet deposition are within a factor of 2 of the corresponding observations and within a factor of 5 for oxidized mercury and dry deposition. The statistical performance of GNAQPMS-Hg is comparable with that of other state-of-the-art Hg models (Bullock et al., 2008; Ryaboshapko et al., 2007; Pirrone and Keating, 2010).

\subsubsection{East Asia versus North America and Europe}

As illustrated in Table 3, the model statistical performance for all $\mathrm{Hg}$ parameters in North America and Europe is better than in East Asia. For example, the RMSEs between simulated and observed TGM over North America and Europe are 0.58 and $0.17 \mathrm{ng} \mathrm{m}^{-3}$ but up to $3.61 \mathrm{ng} \mathrm{m}^{-3}$ over East Asia. The poor model performance over East Asia is prob- ably caused by the following reasons. Firstly, there are differences between simulated and observed data periods. $\mathrm{Hg}$ measurements over East Asia (especially China) are mainly taken from recent years, and the observed values are higher than in year 2001, which may lead to model underestimation. For example, anthropogenic $\mathrm{Hg}$ emissions in China increased by $164 \%$ between 1992 and 2007 (Liang et al., 2013). Secondly, there is a much higher spatial variation ratio (SVR, see Table 3) for $\mathrm{Hg}$ parameters in East Asia than in North America and Europe. This implies that there are very intense spatial variations in surface $\mathrm{Hg}$ concentrations and deposition over East Asia which cannot be resolved at the coarse horizontal resolution used in global models (see Sect. 3.7.2). Thirdly, there are large uncertainties in emission inventories over East Asia. Large underestimations in anthropogenic $\mathrm{Hg}$ emissions over East Asia have been demonstrated in several previous studies (Jaffe et al., 2005; Pan et al., 2007; Friedli et al., 2004; Song et al., 2015). This is consistent with the simulated results in this study. Except for the above factors, missing some chemical and physical processes (e.g., gas-particle partitioning of $\mathrm{Hg}(\mathrm{II})$, in-plume reduction of $\mathrm{Hg}(\mathrm{II})$, and dynamic land re-emission) in the present model might also contribute to the poor model performance over East Asia.

\subsubsection{Global versus nested simulations}

In order to assess the impact of resolution on model predictions, an online nested simulation with higher resolution $\left(0.33^{\circ} \times 0.33^{\circ}\right)$ over East Asia was conducted and compared to the global simulation with lower resolution $\left(1^{\circ} \times 1^{\circ}\right)$. Emissions, meteorology, deposition and chemistry are self-consistent between the global and nested domains. The nested simulation uses higher resolution model inputs (e.g., topography, meteorology, emissions) and thus has the potential to better resolve high spatial variability of $\mathrm{Hg}$ concentrations and deposition in regional and local scales.

Figures 7 and 9 compare the spatial distributions of simulated annual mercury wet deposition, accumulated precipitation and dry deposition over East Asia between the global and nested simulations. Although the global and nested simulations predict similar large-scale patterns for $\mathrm{Hg}$ deposition, the nested simulation resolves many fine features which are lost in the global simulation by horizontal averaging. Firstly, in the nested domain, high-deposition fluxes become more concentrated in regions with large emissions or precipitation resulting in higher spatial variability in deposition. Secondly, the nested simulation reveals elevated wet deposition in southwestern China due to frequent orographic and convective precipitation. Finally, the nested simulation shows a more detailed land/ocean contrast in deposition over coastal regions. For example, over the coastal regions of southeastern China and Japan, wet deposition increases due to scavenging of local emissions and enhanced precipitation (Fig. 7) while dry deposition decreases are associated with the lower dry deposition velocity of $\operatorname{Hg}(0)$ over land than 


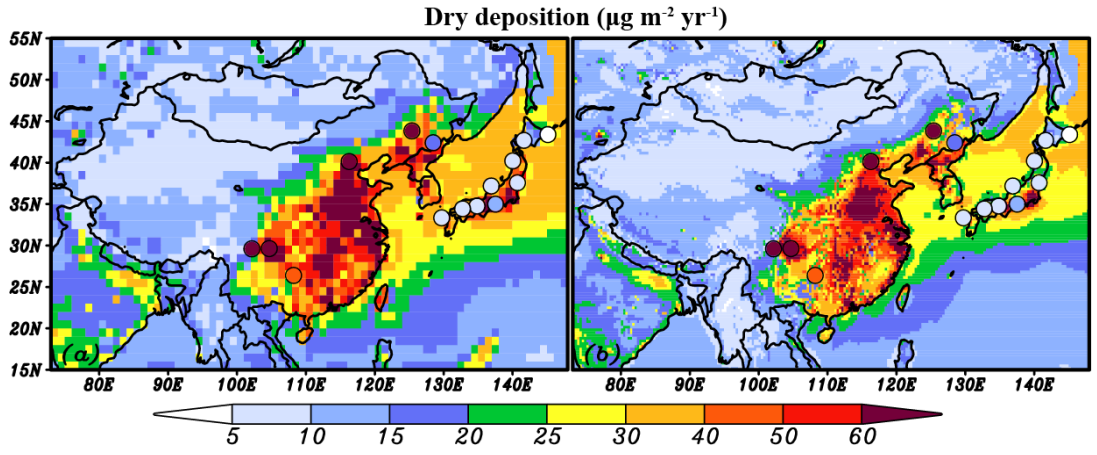

Figure 9. Simulated annual mercury dry deposition $\left(\mu \mathrm{g} \mathrm{m}^{-2} \mathrm{yr}^{-1}\right)$ over East Asia in the global (a) and nested (b) domains in 2001. Overlaid points show observations collected from the literature. Note that observations and simulated results are not in the same year.
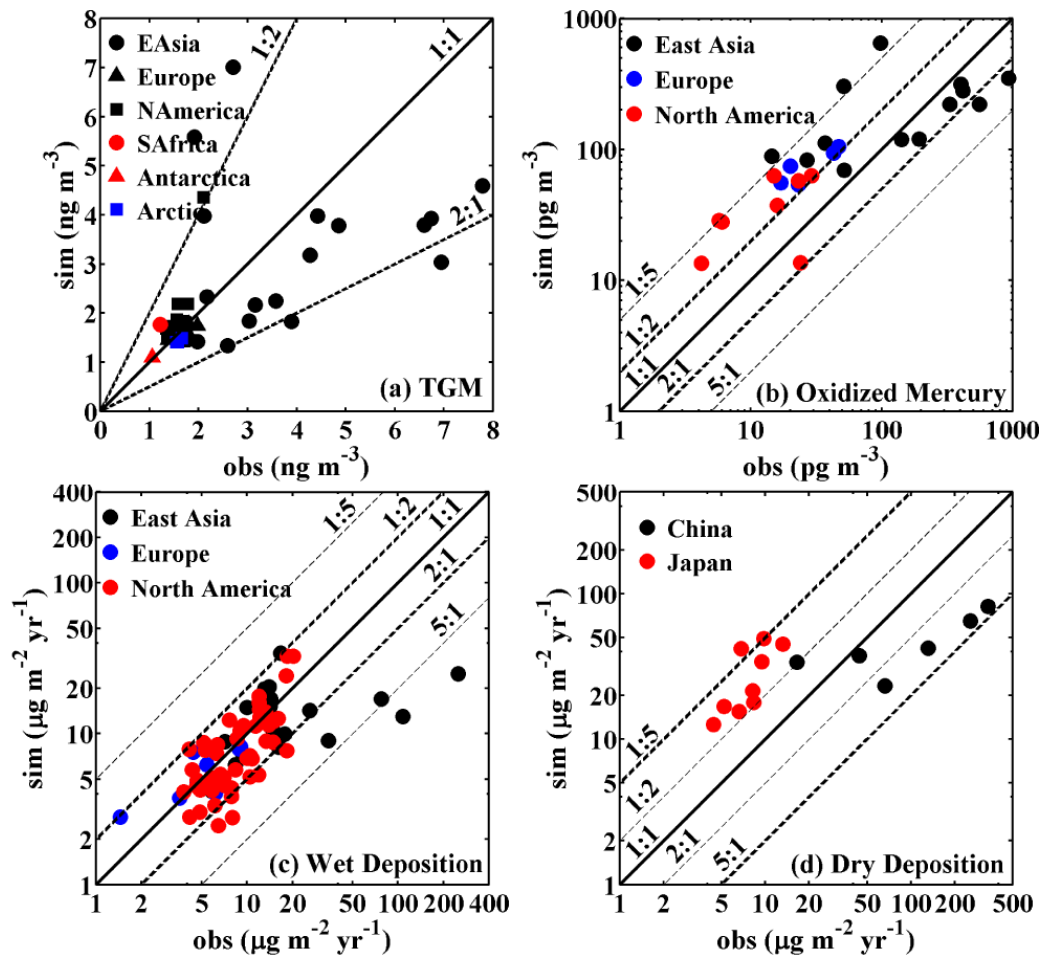

Figure 10. Simulated vs. observed (a) TGM $\left(\mathrm{ng} \mathrm{m}^{-3}\right)$, (b) oxidized mercury $\left(\mathrm{pg} \mathrm{m}^{-3}\right)$, (c) wet deposition $\left(\mu \mathrm{g} \mathrm{m}^{-2} \mathrm{yr}^{-1}\right),(\mathbf{d}) \mathrm{dry} \mathrm{deposition}$ $\left(\mu \mathrm{g} \mathrm{m}^{-2} \mathrm{yr}^{-1}\right)$ in different regions. Note that coordinates are different in different panels.

over ocean (Fig. 9). Our results are similar to those of Zhang et al. (2012), who conducted a nested simulation of Hg over North America using the GEOS-Chem model. More comparisons about the differences of dry and wet deposition and $\mathrm{Hg}$ budgets over East Asia between the two simulations are given in Fig. S16 and Table S6 in the Supplement.

Figure 11 and Table 3 further quantitatively compare the model performance over East Asia between the global and nested domains. In the Taylor diagram (Taylor, 2001), the position of each circle (or square) quantifies how closely the simulated results match observations. We can see that the simulated precipitation, oxidized $\mathrm{Hg}$, wet and dry depo- sition agree better with observations in the nested domain than in the global domain (Fig. 11). The largest improvement is found in the simulated wet deposition. Specifically, the statistical parameter $R$ for simulated wet deposition increases from 0.36 to 0.78 , the NMB decreases from -61 to $-28 \%$, and the RMSE decreases by $24 \%$ (from 60.1 to $45.5 \mu \mathrm{g} \mathrm{m}^{-2} \mathrm{yr}^{-1}$ ) (Table 3). But for TGM, oxidized $\mathrm{Hg}$ and dry deposition, the statistical parameters do not change significantly. For example, the RMSEs of simulated oxidized $\mathrm{Hg}$ and dry deposition decrease by 7 and $2 \%$, respectively, but increase by $7 \%$ for simulated TGM. 


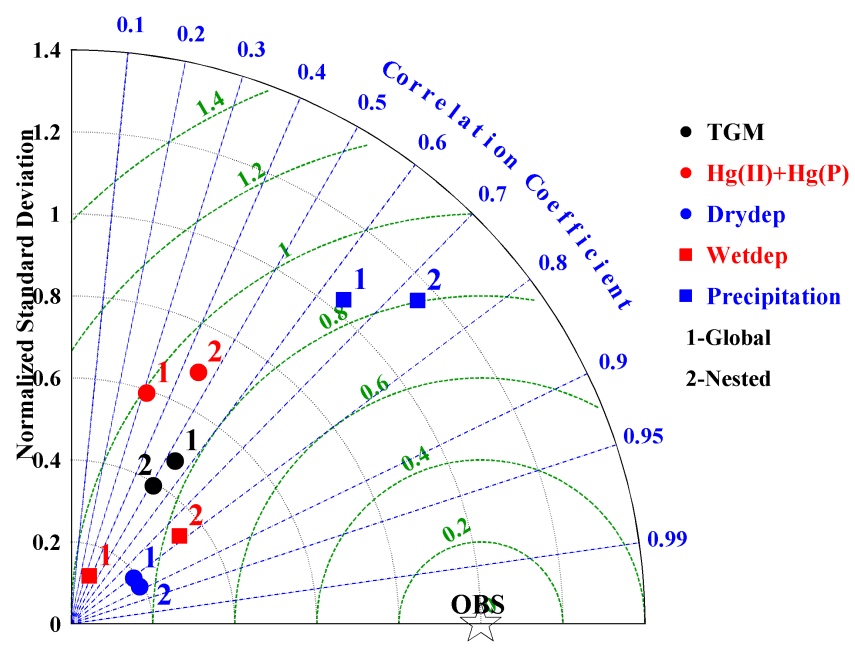

Figure 11. Taylor diagram of simulated annual TGM, $\mathrm{Hg}(\mathrm{II})+\mathrm{Hg}(\mathrm{P})$, dry deposition, wet deposition and precipitation over East Asia in the global and nested domains (denoted as 1 and 2).

Table 4. Statistical comparisons of the online and offline nested simulation results with observations over East Asia ${ }^{\mathrm{a}}$.

\begin{tabular}{|c|c|c|c|c|}
\hline Parameter & Case $^{\mathrm{b}}$ & $R$ & NMB & RMSE \\
\hline \multirow{3}{*}{ TGM } & Base simulation & 0.51 & $-39 \%$ & 3.87 \\
\hline & $3 \mathrm{~h}$ boundary conditions & 0.50 & $-42 \%$ & 3.94 \\
\hline & $6 \mathrm{~h}$ boundary conditions & 0.50 & $-42 \%$ & 3.95 \\
\hline \multirow{3}{*}{ Oxidized mercury } & Base simulation & 0.45 & $-12 \%$ & 242.15 \\
\hline & $3 \mathrm{~h}$ boundary conditions & 0.42 & $-17 \%$ & 251.52 \\
\hline & $6 \mathrm{~h}$ boundary conditions & 0.41 & $-18 \%$ & 252.78 \\
\hline \multirow{3}{*}{ Wet deposition } & Base simulation & 0.78 & $-28 \%$ & 45.47 \\
\hline & $3 \mathrm{~h}$ boundary conditions & 0.78 & $-29 \%$ & 45.75 \\
\hline & $6 \mathrm{~h}$ boundary conditions & 0.78 & $-29 \%$ & 45.78 \\
\hline \multirow{3}{*}{ Dry deposition } & Base simulation & 0.88 & $-42 \%$ & 87.02 \\
\hline & $3 \mathrm{~h}$ boundary conditions & 0.88 & $-44 \%$ & 88.55 \\
\hline & $6 \mathrm{~h}$ boundary conditions & 0.87 & $-45 \%$ & 88.96 \\
\hline
\end{tabular}

\subsubsection{Online versus offline nested simulations}

In order to further justify the online nested method, several model sensitivity experiments were conducted and the simulated results were compared to observations over East Asia. In the base simulation, the online nested method was used and the nested domain got boundary conditions from the global domain every $10 \mathrm{~min}$. In the sensitivity simulations, the offline method was used and the boundary conditions were applied at 3 or $6 \mathrm{~h}$. The differences between the base and the sensitivity simulations were mainly caused by different frequency of boundary conditions. As shown in Table 4, the model performances are similar between the two sensitivity simulations (with 3 and $6 \mathrm{~h}$ offline boundary con-

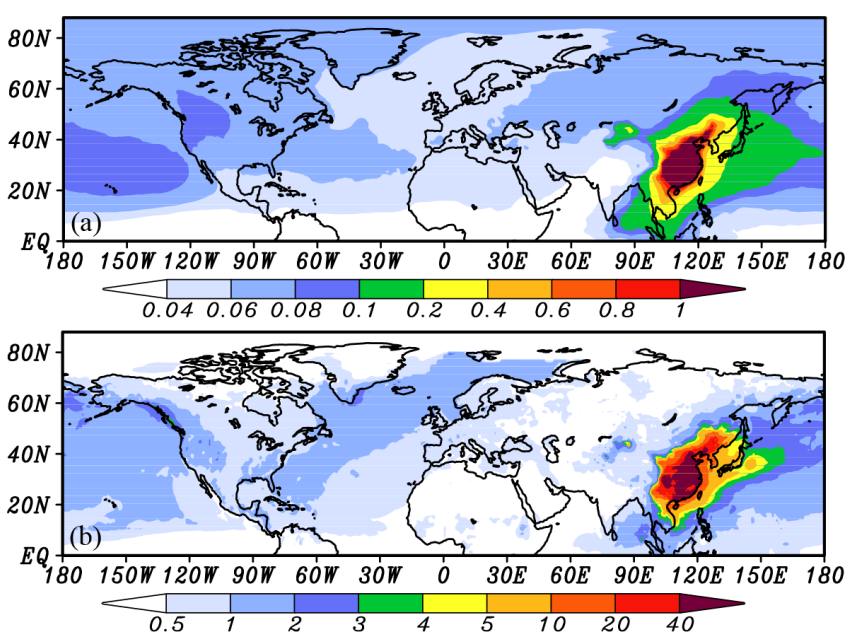

Figure 12. Contributions of Chinese primary anthropogenic sources to (a) annual mercury surface concentrations $\left(\mathrm{ng} \mathrm{m}^{-3}\right)$ and (b) total (wet plus dry) deposition $\left(\mu \mathrm{g} \mathrm{m}^{-2} \mathrm{yr}^{-1}\right)$ in the Northern Hemisphere.

ditions, respectively). While the model performances in the base simulation are slightly better than those in the sensitivity simulations. The largest improvement is found in the simulated oxidized mercury. Specifically, the statistical parameter $R$ for simulated oxidized mercury increases from 0.41 to 0.45 , the NMB decreases from -18 to $-12 \%$, and the RMSE decreases by $4 \%$ compared to the simulated results with $6 \mathrm{~h}$ offline boundary conditions. For wet deposition, little changes are found. This is because $\mathrm{Hg}$ wet deposition is not only affected by air concentrations but also precipitation. These results confirmed the effectiveness of the online nested method.

\section{Impacts of Chinese primary anthropogenic sources on global Hg levels}

Figure 12 shows the contribution of Chinese primary anthropogenic sources (not including re-emission) to annual mercury surface concentrations and total deposition in the Northern Hemisphere, and Fig. 13 gives the corresponding mean percentage contributions over different world regions (defined in Fig. S17 in the Supplement), as derived from a sensitivity simulation with Chinese anthropogenic emissions shut off. In general, the largest percentage contribution is found in China itself, followed by neighboring regions like the Korean Peninsula, Southeast Asia, Mongolia and Japan, but they are relatively small in other regions. Specifically, domestic anthropogenic emissions contribute on average $0.6 \mathrm{ng} \mathrm{m}^{-3}$ (ranging from below 0.1 to above 3.0) to surface $\mathrm{Hg}$ concentrations and $18.4 \mu \mathrm{g} \mathrm{m}^{-2} \mathrm{yr}^{-1}$ (ranging from below 2.0 to above 50.0) to total deposition in China. They account for about $30 \%$ and $62 \%$ on a national basis, respectively. The domestic contribution to deposition consists mainly of the 


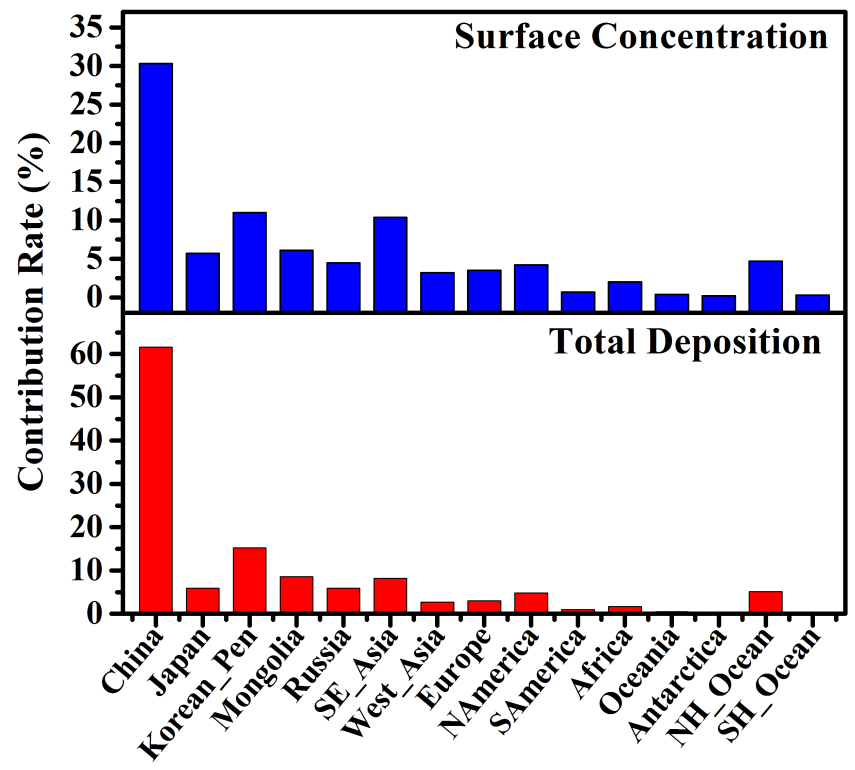

Figure 13. Mean percentage contributions (\%) from Chinese primary anthropogenic sources to annual mercury surface concentrations and total (wet plus dry) deposition over different world regions.

deposition of directly emitted $\mathrm{Hg}(\mathrm{II})$ and $\mathrm{Hg}(\mathrm{P})$ near sources and deposition of $\mathrm{Hg}(\mathrm{II})$ formed by oxidation of Chinese $\mathrm{Hg}(0)$. For neighboring regions, the Chinese anthropogenic contributions to surface $\mathrm{Hg}$ concentrations and deposition are also large. For example, the percentage contributions are $11 \%\left(0.2-0.6 \mathrm{ng} \mathrm{m}^{-3}\right)$ and $15.2 \%\left(8-20 \mathrm{\mu g} \mathrm{m}^{-2} \mathrm{yr}^{-1}\right)$ over the Korean Peninsula, $10.4 \%\left(0.1-0.6 \mathrm{ng} \mathrm{m}^{-3}\right)$ and $8.2 \%\left(1-12 \mu \mathrm{g} \mathrm{m}^{-2} \mathrm{yr}^{-1}\right)$ over Southeast Asia, and $5.7 \%$ $\left(0.1-0.4 \mathrm{ng} \mathrm{m}^{-3}\right)$ and $5.9 \%\left(2-15 \mu \mathrm{g} \mathrm{m}^{-2} \mathrm{yr}^{-1}\right)$ over Japan. For regions far away from China, the percentage contributions are small. They are $4.2 \%\left(0.06-0.1 \mathrm{ng} \mathrm{m}^{-3}\right)$ and $4.8 \%$ $\left(0.5-4 \mu \mathrm{g} \mathrm{m}^{-2} \mathrm{yr}^{-1}\right)$ over North America and $3.5 \%$ (below $0.08 \mathrm{ng} \mathrm{m}^{-3}$ ) and $3.0 \%$ (below $2.0 \mu \mathrm{g} \mathrm{m}^{-2} \mathrm{yr}^{-1}$ ) over Europe. The percentage contributions over North America determined from our simulation are comparable with the modeling study of Lei et al. (2013). They estimated that around $7 \%$ of TGM concentrations and $9 \%$ of total $\mathrm{Hg}$ deposition in the United States resulted from transpacific transport of Asian anthropogenic emissions. Given that about $53 \%$ of Asian anthropogenic $\mathrm{Hg}$ emissions are from China, it is reasonable that our estimated contributions are a little smaller than those reported by Lei et al. (2013).

Finally, there are another two issues which need to be addressed. Firstly, the above analysis mainly focuses on regional average contributions. However, the percentage contributions vary geographically inside the region. As shown in Fig. 12, contributions of domestic anthropogenic emissions to total deposition in central eastern China can exceed $40 \mu \mathrm{g} \mathrm{m}^{-2} \mathrm{yr}^{-1}$, but they are below $5 \mu \mathrm{g} \mathrm{m}^{-2} \mathrm{yr}^{-1}$ in western China. Similarly, previous studies have found that Asian emissions make a much larger contribution to $\mathrm{Hg}$ deposition in the western USA than in the eastern USA (Seigneur et al., 2004; Strode et al., 2008). Secondly, the contributions from re-emission of previously deposited anthropogenic $\mathrm{Hg}$ (treated as natural land or ocean re-emission in GNAQPMS$\mathrm{Hg}$ ) are not taken into account in this study. Of the natural emissions, only one-third is considered not to be influenced by anthropogenic activities at all (Jung et al., 2009). In addition, according to the modeling study of Selin et al. (2008), $31 \%$ (including $22 \%$ primary and $9 \%$ recycled) of the deposition over the USA is from anthropogenic emissions outside of North America. When considering re-emission of previously deposited anthropogenic $\mathrm{Hg}$, this suggests that the foreign anthropogenic contribution would increase by about $42 \%$ (from 22 to $31 \%$ ). If we apply the same scaling factor to our attribution results, then the estimated Chinese anthropogenic contributions to $\mathrm{Hg}$ deposition over North America would increase from 4.8 to $6.8 \%$. Therefore, it is also important to consider the re-emission of previously deposited anthropogenic $\mathrm{Hg}$.

\section{Conclusions}

A global nested atmospheric mercury transport model including $\mathrm{Hg}$ emissions, chemical transformation and deposition is introduced in this study. The treatment of $\mathrm{Hg}$ chemistry employs the $\mathrm{O}_{3}-\mathrm{OH}$ oxidation and $\mathrm{SO}_{3}^{2-}-\mathrm{HO}_{2}$ reduction mechanisms. The gas-phase reactions of $\mathrm{Hg}$ are added to the CBM-Z mechanism, while the aqueous-phase reactions and wet deposition of $\mathrm{Hg}$ are calculated through adapting the RADM mechanism. The Wesely (1989) resistance model is used to deal with $\mathrm{Hg}$ dry deposition. The same meteorological fields, emissions, chemical and physical parameterizations are used in the global and nested domains.

The GNAQPMS-Hg model has a global mercury source of $10163 \mathrm{Mg} \mathrm{yr}^{-1}$, including $2488 \mathrm{Mg} \mathrm{yr}^{-1}$ of primary anthropogenic emissions, $675 \mathrm{Mg} \mathrm{yr}^{-1}$ of biomass burning emissions, $2000 \mathrm{Mg} \mathrm{yr}^{-1}$ of land emissions (of which $75 \%$ is reemission), and $5000 \mathrm{Mg} \mathrm{yr}^{-1}$ from the ocean. Dynamic bidirectional air-surface exchange of $\mathrm{Hg}$ is not included in the model. Instead, we simply apply static net emission fluxes to account for natural sources (including re-emission) of $\mathrm{Hg}$, with total emission amounts determined based on published estimates.

Based on existing routine monitoring networks (e.g., MDN, EMEP) and the published literature, global observations including surface $\mathrm{Hg}$ concentrations and deposition are collected for model evaluation. Compared with previous studies, many more observations over East Asia (especially China) are included in our data set. Model evaluation shows that the spatial distribution and seasonal cycle of $\mathrm{Hg}$ concentrations and deposition can be reproduced reasonably well by GNAQPMS-Hg. Overall, the simulated annual TGM and wet deposition match observations within a factor of 2 , 
and within a factor of 5 for oxidized mercury and dry deposition. This performance is comparable with other stateof-the-art $\mathrm{Hg}$ models. Some model deficiencies have also been identified. GNAQPMS-Hg is systematically biased low relative to cruise observations in the Northern Hemisphere, due to poor representation of the air-sea exchange mechanism for Hg. GNAQPMS-Hg overestimates oxidized mercury concentrations in most parts of the world which may partially be caused by excessive oxidation of $\mathrm{Hg}(0)$ by relatively high concentrations of $\mathrm{OH}$ and $\mathrm{O}_{3}$ and uncertainties associated with $\mathrm{Hg}$ chemical speciation in emission inventories. The model performs significantly better in North America and Europe than in East Asia. This can probably be attributed to the large uncertainties in emission inventories, coarse model resolution and inconsistency between the simulation and observation periods in East Asia. An online nested simulation with higher resolution $\left(0.33^{\circ} \times 0.33^{\circ}\right)$ over East Asia was conducted to examine the impact of horizontal resolution on model predictions. Relative to the global simulation, the nested simulation can better resolve high spatial variability of $\mathrm{Hg}$ concentrations and deposition over East Asia and can better capture features such as higher wet deposition due to orographic and convective precipitation, and land/ocean contrast. Statistically, the RMSE of simulated wet deposition over East Asia is reduced by $24 \%$ in the nested simulation.

To quantify the impacts of Chinese anthropogenic sources on global $\mathrm{Hg}$ levels, a model sensitivity simulation was conducted with Chinese anthropogenic emissions shut off. The results show that these sources contribute 30 and $62 \%$ of surface mercury concentrations and deposition over China. Outside of China, the largest percentage contributions of 11 and $15.2 \%$ are found in the Korean Peninsula, followed by Southeast Asia (10.4 and 8.2\%), Mongolia (6.1 and 8.6\%), and Japan (5.7 and 5.9\%). For regions far away from China, the percentage contributions are relatively small (e.g., 4.2 and $4.8 \%$ over North America; 3.5 and $3.0 \%$ over Europe).

To perfect the model, future improvements will be focused on the following aspects: (1) employing dynamic parameterizations for bidirectional air-surface (sea and land) exchange of $\mathrm{Hg}$ (Selin et al., 2008; Bash, 2010; Strode et al., 2007) to better reflect natural emissions (including re-emission), (2) including fast in-plume reduction of $\mathrm{Hg}$ (II) to better characterize $\mathrm{Hg}$ (II) distribution near large point sources (Amos et al., 2012), and (3) reducing uncertainties in the anthropogenic $\mathrm{Hg}$ emission inventory, especially the $\mathrm{Hg}$ speciation profile. Finally, establishing routine $\mathrm{Hg}$ monitoring networks would also be very helpful for enhancing and improving modeling studies in East Asia.

\section{Code availability}

Please contact Huansheng Chen (email: chenhuansheng@mail.iap.ac.cn) to obtain the source code of GNAQPMS-Hg.

\section{The Supplement related to this article is available online at doi:10.5194/gmd-8-2857-2015-supplement.}

Acknowledgements. This work is funded by the National Natural Science Foundation of China China (41405119, 41225019), the National Key Technology R\&D Program (2014BAC21B02), the Environmental Public Welfare Research Project (201509014), the National Basic Research Program of China (2010CB951800) and the CAS Strategic Priority Research Program (XDB05030200 and XDB05030101). We thank the GEOS-Chem Hg modeling group for sharing observational data of $\mathrm{Hg}$.

Edited by: O. Boucher

\section{References}

AMAP/UNEP: Technical Background Report to the Global Atmospheric Mercury Assessment, Tech. rep., Arctic Monitoring and Assessment Programme/UNEP Chemicals Branch, available at: http://www.unep.org/chemicalsandwaste/Metals/ Mercury/Informationmaterials/ReportsandPublications/tabid/ 3593/Default.aspx (last access: 9 September 2015), 2008.

AMAP/UNEP: Technical Background Report for the Global Mercury Assessment 2013, Tech. rep., Arctic Monitoring and Assessment Programme AMAP and United Nations Environment Programme (UNEP) Chemicals Branch, available at: http://www.unep.org/hazardoussubstances/Mercury/ Informationmaterials/ReportsandPublications/tabid/3593/ Default.aspx (last access: 9 September 2015), 2013.

Amos, H. M., Jacob, D. J., Holmes, C. D., Fisher, J. A., Wang, Q., Yantosca, R. M., Corbitt, E. S., Galarneau, E., Rutter, A. P., Gustin, M. S., Steffen, A., Schauer, J. J., Graydon, J. A., Louis, V. L. St., Talbot, R. W., Edgerton, E. S., Zhang, Y., and Sunderland, E. M.: Gas-particle partitioning of atmospheric $\mathrm{Hg}$ (II) and its effect on global mercury deposition, Atmos. Chem. Phys., 12, 591-603, doi:10.5194/acp-12-591-2012, 2012.

Ariya, P. A., Khalizov, A., and Gidas, A.: Reactions of gaseous mercury with atomic and molecular halogens: Kinetics, product studies, and atmospheric implications, J. Phys. Chem. A, 106, 73107320, doi:10.1021/jp020719o, 2002.

Bash, J. O.: Description and initial simulation of a dynamic bidirectional air-surface exchange model for mercury in Community Multiscale Air Quality (CMAQ) model, J. Geophys. Res.Atmos., 115, D06305, doi:10.1029/2009jd012834, 2010.

Bergan, T. and Rodhe, H.: Oxidation of elemental mercury in the atmosphere: constraints imposed by global scale modelling, J. Atmos. Chem., 40, 191-212, doi:10.1023/a:1011929927896, 2001.

Bullock, O. R. and Brehme, K. A.: Atmospheric mercury simulation using the CMAQ model: formulation description and analysis of wet deposition results, Atmos. Environ., 36, 2135-2146, doi:10.1016/s1352-2310(02)00220-0, 2002.

Bullock Jr., O. R., Atkinson, D., Braverman, T., Civerolo, K., Dastoor, A., Davignon, D., Ku, J.-Y., Lohman, K., Myers, T. C., Park, R. J., Seigneur, C., Selin, N. E., Sistla, G., and Vijayaraghavan, K.: The North American Mercury Model Inter- 
comparison Study (NAMMIS): Study description and modelto-model comparisons, J. Geophys. Res.-Atmos., 113, D17310, doi:10.1029/2008jd009803, 2008.

Chang, J. S., Brost, R. A., Isaksen, I. S. A., Madronich, S., Middleton, P., Stockwell, W. R., and Walcek, C. J.: A threedimensional Eulerian acid deposition model: Physical concepts and formulation, J. Geophys. Res.-Atmos., 92, 14681-14700, doi:10.1029/JD092iD12p14681, 1987.

Christensen, J. H., Brandt, J., Frohn, L. M., and Skov, H.: Modelling of Mercury in the Arctic with the Danish Eulerian Hemispheric Model, Atmos. Chem. Phys., 4, 2251-2257, doi:10.5194/acp-42251-2004, 2004.

Clever, H. L., Johnson, S. A., and Derrick, M. E.: The solubility of mercury and some sparingly soluble mercury salts in water and aqueous-electrolyte solutions, J. Phys. Chem. Ref. Data, 14, 631-681, 1985.

Corbitt, E. S., Jacob, D. J., Holmes, C. D., Streets, D. G., and Sunderland, E. M.: Global source-receptor relationships for mercury deposition under present-day and 2050 emissions scenarios, Environ. Sci. Technol., 45, 10477-10484, doi:10.1021/es202496y, 2011.

Dastoor, A. P. and Durnford, D. A.: Arctic Ocean: Is It a Sink or a Source of Atmospheric Mercury, Environ. Sci. Technol., 48, 1707-1717, 2014.

De Simone, F., Gencarelli, C. N., Hedgecok, I. M., and Pirrone, N.: Global atmospheric cycle of mercury: a model study on the impact of oxidation mechanisms, Environ. Sci. Pollut. Res., 21, 4110-4123, 2014.

ENVIRON: User's guide for Comprehensive Air Quality Model with Extensions Version 5.40, ENVIRON International Corporation, Novato, California, 2011.

Frank, D. G.: Mineral Resource Data System (MRDS) data in ArcView shape file format, for spatial data delivery project, U.S. Geol. Surv., Spokane, Wash., 1999.

Friedli, H. R., Radke, L. F., Prescott, R., Li, P., Woo, J. H., and Carmichael, G. R.: Mercury in the atmosphere around Japan, Korea, and China as observed during the 2001 ACEAsia field campaign: Measurements, distributions, sources, and implications, J. Geophys. Res.-Atmos., 109, D19s25, doi:10.1029/2003jd004244, 2004.

Friedli, H. R., Arellano, A. F., Cinnirella, S., and Pirrone, N.: Initial estimates of mercury emissions to the atmosphere from global biomass burning, Environ. Sci. Technol., 43, 3507-3513, doi:10.1021/es802703g, 2009.

Fu, X., Feng, X., Sommar, J., and Wang, S.: A review of studies on atmospheric mercury in China, Sci. Total Environ., 421, 73-81, doi:10.1016/j.scitotenv.2011.09.089, 2012.

Ge, B., Wang, Z., Xu, X., Wu, J., Yu, X., and Li, J.: Wet deposition of acidifying substances in different regions of China and the rest of East Asia: Modeling with updated NAQPMS, Environ. Pollut., 187, 10-21, doi:10.1016/j.envpol.2013.12.014, 2014.

Gencarelli, C. N., De Simone, F., Hedgecok, I. M., Sprovieri, F., and Pirrone, N.: Development and application of a regional-scale atmospheric mercury model based on WRF/Chem: a Mediterranean area investigation, Environ. Sci. Pollut. Res., 21, 40954109, 2014.

Granier, C., Lamarque, J. F., Mieville, A., Muller, J. F., and Olivier, J.: POET, a database of surface emissions of ozone precur- sors, tech. report, available at: http://www.aero.jussieu.fr/projet/ ACCENT/POET.php (last access: 10 June 2013), 2005.

Guenther, A., Karl, T., Harley, P., Wiedinmyer, C., Palmer, P. I., and Geron, C.: Estimates of global terrestrial isoprene emissions using MEGAN (Model of Emissions of Gases and Aerosols from Nature), Atmos. Chem. Phys., 6, 3181-3210, doi:10.5194/acp-63181-2006, 2006.

Hall, B.: The gas phase oxidation of elemental mercury by ozone, Water Air Soil Pollut., 80, 301-315, doi:10.1007/bf01189680, 1995.

Hall, B. and Bloom., N.: Report to EPRI, Palo Alto, CA., USA, 1993.

Harada, M.: Minamata Disease - Methylmercury poisoning in Japan caused by environmental pollution, Crit. Rev. Toxicol., 25, 1-24, doi:10.3109/10408449509089885, 1995.

Holmes, C. D., Jacob, D. J., Corbitt, E. S., Mao, J., Yang, X., Talbot, R., and Slemr, F.: Global atmospheric model for mercury including oxidation by bromine atoms, Atmos. Chem. Phys., 10, 12037-12057, doi:10.5194/acp-10-12037-2010, 2010.

Horowitz, L. W., Walters, S., Mauzerall, D. L., Emmons, L. K., Rasch, P. J., Granier, C., Tie, X. X., Lamarque, J. F., Schultz, M. G., Tyndall, G. S., Orlando, J. J., and Brasseur, G. P.: A global simulation of tropospheric ozone and related tracers: Description and evaluation of MOZART, version 2, J. Geophys. Res.-Atmos., 108, 4784, doi:10.1029/2002jd002853, 2003.

Jaffe, D. and Strode, S.: Sources, fate and transport of atmospheric mercury from Asia, Environ. Chem., 5, 121-126, doi:10.1071/en08010, 2008.

Jaffe, D., Prestbo, E., Swartzendruber, P., Weiss-Penzias, P., Kato, S., Takami, A., Hatakeyama, S., and Kajii, Y.: Export of atmospheric mercury from Asia, Atmos. Environ., 39, 3029-3038, doi:10.1016/j.atmosenv.2005.01.030, 2005.

Jiang, G., Shi, J., and Feng, X.: Mercury pollution in China: An overview of the past and current sources of the toxic metal, Environ. Sci. Technol., 40, 3673-3678, 2006.

Jung, G., Hedgecock, I. M., and Pirrone, N.: ECHMERIT V1.0 - a new global fully coupled mercury-chemistry and transport model, Geosci. Model Dev., 2, 175-195, doi:10.5194/gmd-2175-2009, 2009.

Keeler, G. J., Pirrone, N., Bullock, R., and Sillman, S.: The need for a coordinated global $\mathrm{Hg}$ monitoring network for global and regional models validation, in: Mercury Fate and Transport in the Global Atmosphere, edited by: Mason, R., and Pirrone, N., Springer, USA, 391-424, 2009.

Lamarque, J.-F., Bond, T. C., Eyring, V., Granier, C., Heil, A., Klimont, Z., Lee, D., Liousse, C., Mieville, A., Owen, B., Schultz, M. G., Shindell, D., Smith, S. J., Stehfest, E., Van Aardenne, J., Cooper, O. R., Kainuma, M., Mahowald, N., McConnell, J. R., Naik, V., Riahi, K., and van Vuuren, D. P.: Historical (1850-2000) gridded anthropogenic and biomass burning emissions of reactive gases and aerosols: methodology and application, Atmos. Chem. Phys., 10, 7017-7039, doi:10.5194/acp10-7017-2010, 2010.

Lamborg, C. H., Fitzgerald, W. F., O'Donnell, J., and Torgersen, T.: A non-steady-state compartmental model of globalscale mercury biogeochemistry with interhemispheric atmospheric gradients, Geochim. Cosmochim. Ac., 66, 1105-1118, doi:10.1016/s0016-7037(01)00841-9, 2002. 
Lawrence, M. G., Jöckel, P., and von Kuhlmann, R.: What does the global mean $\mathrm{OH}$ concentration tell us?, Atmos. Chem. Phys., 1, 37-49, doi:10.5194/acp-1-37-2001, 2001.

Lei, H., Liang, X.-Z., Wuebbles, D. J., and Tao, Z.: Model analyses of atmospheric mercury: present air quality and effects of transpacific transport on the United States, Atmos. Chem. Phys., 13, 10807-10825, doi:10.5194/acp-13-10807-2013, 2013.

Li, J., Wang, Z., Akimoto, H., Gao, C., Pochanart, P., and Wang, X.: Modeling study of ozone seasonal cycle in lower troposphere over east Asia, J. Geophys. Res.-Atmos., 112, D22s25, doi:10.1029/2006jd008209, 2007.

Li, J., Wang, Z., Wang, X., Yamaji, K., Takigawa, M., Kanaya, Y., Pochanart, P., Liu, Y., Irie, H., Hu, B., Tanimoto, H., and Akimoto, H.: Impacts of aerosols on summertime tropospheric photolysis frequencies and photochemistry over Central Eastern China, Atmos. Environ., 45, 1817-1829, doi:10.1016/j.atmosenv.2011.01.016, 2011.

Li, J., Wang, Z., Zhuang, G., Luo, G., Sun, Y., and Wang, Q.: Mixing of Asian mineral dust with anthropogenic pollutants over East Asia: a model case study of a super-duststorm in March 2010, Atmos. Chem. Phys., 12, 7591-7607, doi:10.5194/acp-127591-2012, 2012.

Liang, S., Xu, M., Liu, Z., Suh, S. and Zhang T.: Socioeconomic Drivers of Mercury Emissions in China from 1992 to 2007, Environ. Sci. Technol., 47, 3234-3240, 2013.

Lin, C. J. and Pehkonen, S. O.: Aqueous free radical chemistry of mercury in the presence of iron oxides and ambient aerosol, Atmos. Environ., 31, 4125-4137, doi:10.1016/S13522310(97)00269-0, 1997.

Lin, C. J. and Pehkonen, S. O.: Oxidation of elemental mercury by aqueous chlorine $\left(\mathrm{HOCl} / \mathrm{OCl}^{-}\right)$: Implications for tropospheric mercury chemistry, J. Geophys. Res.-Atmos., 103, 28093-28102, doi:10.1029/98jd02304, 1998.

Lin, C. J. and Pehkonen, S. O.: The chemistry of atmospheric mercury: a review, Atmos. Environ., 33, 2067-2079, doi:10.1016/s1352-2310(98)00387-2, 1999.

Lin, C. J., Pongprueks, P., Ho, T. C., and Jang, C.: Development of mercury modeling schemes within CMAQ framework: Science and model implementation issues, In: Proceedings of the 2004 CMAS Models-3 Conference, Research Triangle Park, NC, 1820 October (CD-ROM), 2004.

Lin, C. J., Pongprueksa, P., Lindberg, S. E., Pehkonen, S. O., Byun, D., and Jang, C.: Scientific uncertainties in atmospheric mercury models I: Model science evaluation, Atmos. Environ., 40, 29112928, doi:10.1016/j.atmosenv.2006.01.009, 2006.

Lindberg, S., Bullock, R., Ebinghaus, R., Engstrom, D., Feng, X., Fitzgerald, W., Pirrone, N., Prestbo, E., and Seigneur, C.: A synthesis of progress and uncertainties in attributing the sources of mercury in deposition, Ambio, 36, 19-32, 2007.

Lindqvist, O. and Rodhe, H.: Atmospheric mercury - A review, Tellus B, 37, 136-159, 1985.

Mason, R.: Mercury emissions from natural processes and their importance in the global mercury cycle, in: Mercury Fate and Transport in the Global Atmosphere, edited by: Mason, R. and Pirrone, N., Springer, USA, 173-191, 2009.

Munthe, J.: The aqueous oxidation of elemental mercury by ozone, Atmos. Environ., 26, 1461-1468, doi:10.1016/09601686(92)90131-4, 1992.
Pacyna, E. G., Pacyna, J. M., Steenhuisen, F., and Wilson, S.: Global anthropogenic mercury emission inventory for 2000, Atmos. Environ., 40, 4048-4063, doi:10.1016/j.atmosenv.2006.03.041, 2006.

Pan, L., Chai, T., Carmichael, G. R., Tang, Y., Streets, D., Woo, J.-H., Friedli, H. R., and Radke, L. F.: Top-down estimate of mercury emissions in China using four-dimensional variational data assimilation, Atmos. Environ., 41, 2804-2819, doi:10.1016/j.atmosenv.2006.11.048, 2007.

Pan, L., Carmichael, G. R., Adhikary, B., Tang, Y., Streets, D., Woo, J.-H., Friedli, H. R., and Radke, L. F.: A regional analysis of the fate and transport of mercury in East Asia and an assessment of major uncertainties, Atmos. Environ., 42, 1144-1159, doi:10.1016/j.atmosenv.2007.10.045, 2008.

Pehkonen, S. O. and Lin, C. J.: Aqueous photochemistry of mercury with organic acids, J. Air Waste Manage. Assoc., 48, 144-150, doi:10.1080/10473289.1998.10463661, 1998.

Pirrone, N. and Keating, T.: Hemispheric Transport of Air Pollution 2010 Part B: Mercury, United Nations, New York and Geneva, 210 pp., 2010.

Pirrone, N., Cinnirella, S., Feng, X., Finkelman, R. B., Friedli, H. R., Leaner, J., Mason, R., Mukherjee, A. B., Stracher, G. B., Streets, D. G., and Telmer, K.: Global mercury emissions to the atmosphere from anthropogenic and natural sources, Atmos. Chem. Phys., 10, 5951-5964, doi:10.5194/acp-10-59512010, 2010.

Price, C., Penner, J., and Prather, $\mathrm{M} .: \mathrm{NO}_{x}$ from lightning: 1. Global distribution based on lightning physics, J. Geophys. Res.-Atmos., 102, 5929-5941, doi:10.1029/96jd03504, 1997.

Ryaboshapko, A., Bullock, O. R., Jr., Christensen, J., Cohen, M., Dastoor, A., Ilyin, I., Petersen, G., Syrakov, D., Travnikov, O., Artz, R. S., Davignon, D., Draxler, R. R., Munthe, J., and Pacyna, J.: Intercomparison study of atmospheric mercury models: 2. Modelling results vs. long-term observations and comparison of country deposition budgets, Sci. Total Environ., 377, 319-333, doi:10.1016/j.scitotenv.2007.01.071, 2007.

Sanemasa, I.: The solubility of elemental mercury vapor in water, Bull. Chem. Soc. Jpn., 48, 1795-1798, 1975.

Schroeder, W. H. and Munthe, J.: Atmospheric mercury - An overview, Atmos. Environ., 32, 809-822, doi:10.1016/s13522310(97)00293-8, 1998.

Schroeder, W. H., Anlauf, K. G., Barrie, L. A., Lu, J. Y., Steffen, A., Schneeberger, D. R., and Berg, T.: Arctic springtime depletion of mercury, Nature, 394, 331-332, doi:10.1038/28530, 1998.

Seigneur, C., Abeck, H., Chia, G., Reinhard, M., Bloom, N. S., Prestbo, E., and Saxena, P.: Mercury adsorption to elemental carbon (soot) particles and atmospheric particulate matter, Atmos. Environ., 32, 2649-2657, doi:10.1016/S1352-2310(97)00415-9, 1998.

Seigneur, C., Karamchandani, P., Lohman, K., Vijayaraghavan, K., and Shia, R. L.: Multiscale modeling of the atmospheric fate and transport of mercury, J. Geophys. Res.-Atmos., 106, 27795 27809, doi:10.1029/2000jd000273, 2001.

Seigneur, C., Vijayaraghavan, K., Lohman, K., Karamchandani, P., and Scott, C.: Global source attribution for mercury deposition in the United States, Environ. Sci. Technol., 38, 555-569, doi:10.1021/es034109t, 2004. 
Selin, N. E.: Global biogeochemical cycling of mercury: A review, Annu. Rev. Environ. Resour., 34, 43-63, doi:10.1146/annurev.environ.051308.084314, 2009.

Selin, N. E., Jacob, D. J., Park, R. J., Yantosca, R. M., Strode, S., Jaegle, L., and Jaffe, D.: Chemical cycling and deposition of atmospheric mercury: Global constraints from observations, J. Geophys. Res.-Atmos., 112, D02308, doi:10.1029/2006jd007450, 2007.

Selin, N. E., Jacob, D. J., Yantosca, R. M., Strode, S., Jaegle, L., and Sunderland, E. M.: Global 3-D land-ocean-atmosphere model for mercury: Present-day versus preindustrial cycles and anthropogenic enrichment factors for deposition, Global Biogeochem. Cy., 22, Gb3099, doi:10.1029/2008gb003282, 2008.

Shia, R. L., Seigneur, C., Pai, P., Ko, M., and Dak Sze, N.: Global simulation of atmospheric mercury concentrations and deposition fluxes, J. Geophys. Res.-Atmos., 104, 23747-23760, 1999.

Sillen, L. G., Martell, A. E., and Bjerrum, J.: Stability constants of metal-ion complexes, Chem. Soc., 17, 754 pp., 1964.

Soerensen, A. L., Skov, H., Jacob, D. J., Soerensen, B. T., and Johnson, M. S.: Global concentrations of gaseous elemental mercury and reactive gaseous mercury in the marine boundary layer, Environ. Sci. Technol., 44, 7425-7430, doi:10.1021/es903839n, 2010a.

Soerensen, A. L., Sunderland, E. M., Holmes, C. D., Jacob, D. J., Yantosca, R. M., Skov, H., Christensen, J. H., Strode, S. A., and Mason, R. P.: An improved global model for air-sea exchange of mercury: High concentrations over the North Atlantic, Environ. Sci. Technol., 44, 8574-8580, doi:10.1021/es102032g, 2010b.

Soerensen, A. L., Jacob, D. J., Streets, D., Witt, M., Ebinghaus, R., Mason, R. P., Andersson, M., and Sunderland, E. M.: Multidecadal decline of mercury in the North Atlantic atmosphere explained by changing subsurface seawater concentrations, Geophys. Res. Lett., 39, L21810, doi:10.1029/2012GL053736, 2012.

Sommar, J., Gardfeldt, K., Stromberg, D., and Feng, X. B.: A kinetic study of the gas-phase reaction between the hydroxyl radical and atomic mercury, Atmos. Environ., 35, 3049-3054, doi:10.1016/s1352-2310(01)00108-x, 2001.

Song, S., Selin, N. E., Soerensen, A. L., Angot, H., Artz, R., Brooks, S., Brunke, E.-G., Conley, G., Dommergue, A., Ebinghaus, R., Holsen, T. M., Jaffe, D. A., Kang, S., Kelley, P., Luke, W. T., Magand, O., Marumoto, K., Pfaffhuber, K. A., Ren, X., Sheu, G.-R., Slemr, F., Warneke, T., Weigelt, A., Weiss-Penzias, P., Wip, D. C., and Zhang, Q.: Top-down constraints on atmospheric mercury emissions and implications for global biogeochemical cycling, Atmos. Chem. Phys., 15, 7103-7125, doi:10.5194/acp-157103-2015, 2015.

Sprovieri, F., Pirrone, N., Ebinghaus, R., Kock, H., and Dommergue, A.: A review of worldwide atmospheric mercury measurements, Atmos. Chem. Phys., 10, 8245-8265, doi:10.5194/acp10-8245-2010, 2010.

Steffen, A., Schroeder, W., Macdonald, R., Poissant, L., and Konoplev, A.: Mercury in the Arctic atmosphere: An analysis of eight years of measurements of GEM at Alert (Canada) and a comparison with observations at Amderma (Russia) and Kuujjuarapik (Canada), Sci. Total Environ., 342, 185-198, doi:10.1016/j.scitotenv.2004.12.048, 2005.

Strode, S. A., Jaegle, L., Selin, N. E., Jacob, D. J., Park, R. J., Yantosca, R. M., Mason, R. P., and Slemr, F.: Air-sea exchange in the global mercury cycle, Global Biogeochem. Cy., 21, Gb1017, doi:10.1029/2006gb002766, 2007.

Strode, S. A., Jaegle, L., Jaffe, D. A., Swartzendruber, P. C., Selin, N. E., Holmes, C., and Yantosca, R. M.: Trans-Pacific transport of mercury, J. Geophys. Res.-Atmos., 113, D15305, doi:10.1029/2007jd009428, 2008.

Tang, X., Wang, Z., Zhu, J., Gbaguidi, A. E., Wu, Q., Li, J., and Zhu, T.: Sensitivity of ozone to precursor emissions in urban Beijing with a Monte Carlo scheme, Atmos. Environ., 44, 3833-3842, doi:/10.1016/j.atmosenv.2010.06.026, 2010.

Taylor, K. E.: Summarizing multiple aspects of model performance in a single diagram, J. Geophys. Res.-Atmos., 106, 7183-7192, doi:10.1029/2000jd900719, 2001.

Temme, C., Slemr, F., Ebinghaus, R., and Einax, J. W.: Distribution of mercury over the Atlantic Ocean in 1996 and 19992001, Atmos. Environ., 37, 1889-1897, doi:10.1016/s13522310(03)00069-4, 2003.

Tokos, J. J. S., Hall, B., Calhoun, J. A., and Prestbo, E. M.: Homogeneous gas-phase reaction of $\mathrm{Hg} 0$ with $\mathrm{H}_{2} \mathrm{O}_{2}, \mathrm{O}_{3}, \mathrm{CH} 3 \mathrm{I}$, and (CH3)(2)S: Implications for atmospheric Hg cycling, Atmos. Environ., 32, 823-827, doi:10.1016/s1352-2310(97)00171-4, 1998.

Travnikov, O.: Contribution of the intercontinental atmospheric transport to mercury pollution in the Northern Hemisphere, Atmos. Environ., 39, 7541-7548, doi:10.1016/j.atmosenv.2005.07.066, 2005.

Travnikov, O. and Ilyin, I.: The EMEP/MSC-E mercury modeling system, in: Mercury Fate and Transport in the Global Atmosphere, edited by: Mason, R., and Pirrone, N., Springer, USA, 571-587, 2009.

Van Loon, L., Mader, E., and Scott, S. L.: Reduction of the aqueous mercuric ion by sulfite?: UV spectrum of $\mathrm{HgSO}_{3}$ and its intramolecular redox reaction, J. Phys. Chem. A, 104, 1621-1626, doi:10.1021/jp994268s, 2000.

Van Loon, L. L., Mader, E. A., and Scott, S. L.: Sulfite stabilization and reduction of the aqueous mercuric ion: Kinetic determination of sequential formation constants, J. Phys. Chem. A, 105, 31903195, doi:10.1021/jp003803h, 2001.

Vijayaraghavan, K., Karamchandani, P., Seigneur, C., Balmori, R., and Chen, S.-Y.: Plume-in-grid modeling of atmospheric mercury, J. Geophys. Res., 113, D24305, doi:10.1029/2008JD010580, 2008.

Voulgarakis, A., Naik, V., Lamarque, J.-F., Shindell, D. T., Young, P. J., Prather, M. J., Wild, O., Field, R. D., Bergmann, D., CameronSmith, P., Cionni, I., Collins, W. J., Dalsøren, S. B., Doherty, R. M., Eyring, V., Faluvegi, G., Folberth, G. A., Horowitz, L. W., Josse, B., MacKenzie, I. A., Nagashima, T., Plummer, D. A., Righi, M., Rumbold, S. T., Stevenson, D. S., Strode, S. A., Sudo, K., Szopa, S., and Zeng, G.: Analysis of present day and future $\mathrm{OH}$ and methane lifetime in the ACCMIP simulations, Atmos. Chem. Phys., 13, 2563-2587, doi:10.5194/acp-13-25632013, 2013.

Walcek, C. J. and Aleksic, N. M.: A simple but accurate mass conservative, peak-preserving, mixing ratio bounded advection algorithm with Fortran code, Atmos. Environ., 32, 3863-3880, doi:10.1016/s1352-2310(98)00099-5, 1998.

Wang, Q., Fu, Q., Wang, Z., Wang, T., Liu, P., Lu, T., Duan, Y., and Huang, Y.: Application of ensemble numerical model system on the air quality forecast in Shanghai, Environ. Monitor. Forewarn., 2, 1-6 + p. 11, 2010 (in Chinese). 
Wang, Z., Akimoto, H., and Uno, I.: Neutralization of soil aerosol and its impact on the distribution of acid rain over east Asia: Observations and model results, J. Geophys. Res.-Atmos., 107, 4389, doi:10.1029/2001jd001040, 2002.

Wang, Z., Xie, F., Wang, X., An, J., and Zhu, J.: Development and application of Nested Air Quality Prediction Modeling System, Ch. J. Atmos. Sci., 30, 778-790, 2006 (in Chinese).

Wang, Z., Wu, Q., Gbaguidi, A., Yan, P., Zhang, W., Wang, W., and Tang, X.: Ensemble air quality multi-model forecast system for Beijing (EMS-Beijing): Model description and preliminary application, Journal of Nanjing University of Information Science \& Technology (Natural Science Edition), 1, 19-26, 2009 (in Chinese).

Wesely, M. L.: Parameterization of surface resistances to gaseous dry deposition in regional-scale numerical models, Atmos. Environ., 23, 1293-1304, doi:10.1016/0004-6981(89)90153-4, 1989.

Wilson, S. J., Steenhuisen, F., Pacyna, J. M., and Pacyna, E. G.: Mapping the spatial distribution of global anthropogenic mercury atmospheric emission inventories, Atmos. Environ., 40, 46214632, doi:10.1016/j.atmosenv.2006.03.042, 2006.
Wu, Q., Wang, Z., Chen, H., Zhou, W., and Wenig, M.: An evaluation of air quality modeling over the Pearl River Delta during November 2006, Meteorol. Atmos. Phys., 116, 113-132, doi:10.1007/s00703-011-0179-z, 2012.

Yan, X., Ohara, T., and Akimoto, H.: Statistical modeling of global soil NOx emissions, Global Biogeochem. Cy., 19, GB3019, doi:10.1029/2004GB002276, 2005.

Zaveri, R. and Peters, L.: A new lumped structure photochemical mechanism for large-scale applications, J. Geophys. Res.Atmos., 104, 30387-30415, 1999.

Zhang, Y., Jaeglé, L., van Donkelaar, A., Martin, R. V., Holmes, C. D., Amos, H. M., Wang, Q., Talbot, R., Artz, R., Brooks, S., Luke, W., Holsen, T. M., Felton, D., Miller, E. K., Perry, K. D., Schmeltz, D., Steffen, A., Tordon, R., Weiss-Penzias, P., and Zsolway, R.: Nested-grid simulation of mercury over North America, Atmos. Chem. Phys., 12, 6095-6111, doi:10.5194/acp12-6095-2012, 2012. 